\title{
LEAF- AND CELL-LEVEL CARBON CYCLING RESPONSES TO A NITROGEN AND PHOSPHORUS GRADIENT IN TWO ARCTIC TUNDRA SPECIES ${ }^{1}$
}

\author{
Mary A. Heskel ${ }^{2,6}$, O. Roger Anderson ${ }^{3}$, Owen K. Atkin ${ }^{4}$, Matthew H. Turnbull ${ }^{5}$, \\ AND KeVIn L. GRIFFIN ${ }^{2,3}$
}

\begin{abstract}
${ }^{2}$ Department of Ecology, Evolution, \& Environmental Biology, 1200 Amsterdam Avenue, Columbia University, New York, New York 10027 USA; ${ }^{3}$ Department of Biology, Lamont-Doherty Earth Observatory, 6 Marine Biology, 61 Route 9W, Palisades, New York 10964 USA; ${ }^{4}$ Division of Plant Sciences, Building 46, Research School of Biology, The Australian National University, Acton, ACT, 0200 Australia; ${ }^{5}$ School of Biological Sciences, University of Canterbury, Private Bag 4800, Christchurch, 8140 New Zealand
\end{abstract}

\begin{abstract}
- Premise of the study: Consequences of global climate change are detectable in the historically nitrogen- and phosphoruslimited Arctic tundra landscape and have implications for the terrestrial carbon cycle. Warmer temperatures and elevated soil nutrient availability associated with increased microbial activity may influence rates of photosynthesis and respiration.

- Methods: This study examined leaf-level gas exchange, cellular ultrastructure, and related leaf traits in two dominant tundra species, Betula nana, a woody shrub, and Eriophorum vaginatum, a tussock sedge, under a 3-yr-old treatment gradient of nitrogen $(\mathrm{N})$ and phosphorus $(\mathrm{P})$ fertilization in the North Slope of Alaska.

- Key results: Respiration increased with $\mathrm{N}$ and $\mathrm{P}$ addition - the highest rates corresponding to the highest concentrations of leaf $\mathrm{N}$ in both species. The inhibition of respiration by light ("Kok effect") significantly reduced respiration rates in both species $(P<0.001)$, ranged from 12-63\% (mean 34\%), and generally decreased with fertilization for both species. However, in both species, observed rates of photosynthesis did not increase, and photosynthetic nitrogen use efficiency generally decreased under increasing fertilization. Chloroplast and mitochondrial size and density were highly sensitive to $\mathrm{N}$ and $\mathrm{P}$ fertilization $(P<$ 0.001), though species interactions indicated divergent cellular organizational strategies.

- Conclusions: Results from this study demonstrate a species-specific decoupling of respiration and photosynthesis under $\mathrm{N}$ and $P$ fertilization, implying an alteration of the carbon balance of the tundra ecosystem under future conditions.
\end{abstract}

Key words: Arctic tundra; carbon cycling; chloroplasts; light inhibition; mitochondria; nitrogen; phosphorus; photosynthesis; respiration.

The effects of increased nitrogen $(\mathrm{N})$ and phosphorus $(\mathrm{P})$ availability on carbon (C) cycling in Arctic tundra vegetation are important for the current understanding and future predictions of net $\mathrm{C}$ balance. The Arctic tundra is characterized by its vast $\mathrm{C}$ reservoirs (Gorham, 1991; Ping et al., 2008) and $\mathrm{N}$ and P limitation (Shaver and Chapin, 1986; Shaver et al., 1992; Hobbie et al., 2002), with $\mathrm{C}$ accumulating in the deep layer of organic matter sustained by permafrost (Dowding et al., 1981; Robinson and Wookey, 1997). Global change may alter this state (Chapin et al., 1995). Consequences of climate change on Arctic tundra ecosystems are evidenced through multiple cascading environmental and ecological effects, with implications for soil nutrient availability, changes in soil microbial mineralization, and $\mathrm{C}$ cycling. Increases in winter and summer temperatures (Serreze et al., 2000; Chapin et al., 2005; Anderson, 2010), lengthening of snow-free seasons (Stone et al.,

\footnotetext{
${ }^{1}$ Manuscript received 24 May 2012; revision accepted 31 August 2012.

We thank Heather Greaves for help in collecting photosynthesis data and Jim Laundre and others at the Arctic LTER and Toolik Field Station for maintaining the long-term fertilization experiments used in this study. This study was made possible by generous funding from the National Science Foundation (IPY \#07-32664).

${ }^{6}$ Author for correspondence (e-mail: mah2207@columbia.edu), phone: (267) 259-7549
}

doi:10.3732/ajb.1200251
2002), and decreased albedo due to warming and land-surface changes (Chapin et al., 2005; Lundberg and Beringer, 2005) all affect biological processes underlying $\mathrm{N}$ and $\mathrm{P}$ resources for vegetation. Enabled by warmer conditions, the northward expansion of woody shrubs into tussock-dominated tundra continues to change plant community composition (Sturm et al., 2001; Tape et al., 2006). During winter months, the taller canopy height of shrubs allows for greater snowpack, creating an insulating layer that warms soil, and in turn can increase soil nutrient availability (Sturm et al., 2005). This, as well as observed differences in litter quality, decomposition rates, and soil microbial community structure, exhibit how ecosystem $\mathrm{C}, \mathrm{N}$, and $\mathrm{P}$ cycling can be altered under a shift to a more shrub-dominated landscape (Hobbie, 1996; Weintraub and Schimel, 2005; Wallenstein et al., 2007; Wookey et al., 2009). Further, warmer soil temperatures may increase rates of $\mathrm{N}$ and $\mathrm{P}$ mineralization (Nadelhoffer et al., 1991; Jonasson et al., 2004), adding to the available $\mathrm{N}$ pool. Also, despite the remoteness of the Arctic, $\mathrm{N}$ deposition from fossil fuel combustion is detectable (Woodin, 1997; Hodson et al., 2005) and is likely to increase in the future (Galloway et al., 2004). Though the direct anthropogenic source of $\mathrm{N}$ is relatively minimal, the combined impact of warmingmediated biological and environmental processes with deposition, will likely lead to a greater overall availability of limiting nutrients.

Long-term manipulation experiments of soil nutrient fertilization on Arctic tundra vegetation demonstrate the controlling 
influence of $\mathrm{N}$ and $\mathrm{P}$ on aboveground primary productivity (Shaver and Chapin, 1986; Johnson et al., 2000; Bret-Harte et al., 2004; Mack et al., 2004). Community responses to nutrient fertilization are well documented in tundra ecosystems (Shaver and Chapin, 1986; Shaver et al., 1998; Johnson et al., 2000; Hobbie et al., 2002; Bret-Harte et al., 2004; Mack et al., 2004). In tussock tundra, N+P fertilization can result in increased aboveground biomass, attributed to a compositional shift to a greater abundance of woody shrub species like Betula nana (Shaver and Chapin, 1986; Chapin et al., 1995; Bret-Harte et al., 2002; Mack et al., 2004). This shift suggests species and functional group differences that may be reflected in plant gas exchange. In wet sedge tundra, the community-level $\mathrm{CO}_{2}$ fluxes of net ecosystem exchange (NEE), ecosystem respiration (ER), and gross ecosystem productivity (GEP) all increase under $\mathrm{N}+\mathrm{P}$ fertilization, with the response to $\mathrm{P}$ being proportionally greater than that of N (Shaver et al., 1998). Similarly, when Johnson et al. (2000) considered the seasonal and diel impacts of $\mathrm{CO}_{2}$ exchange in the same experimental plots, both ER and GEP were elevated significantly under $\mathrm{N}+\mathrm{P}$ addition and exhibited the greatest divergence from the control plots during the peak season.

Species differences in carbon cycling can be especially important when considering the shifting ecological dynamics of the Arctic tundra. Because woody shrubs like B. nana expand both in individual size and geographic range, comparisons of leaf-level photosynthesis and respiration with the historically dominant tundra tussock Eriophorum vaginatum may strengthen predictions about the future tundra ecosystem function. Despite the large literature on tundra responses to nutrient addition, relatively few studies have examined leaf-level rates of gas exchange (Baddeley et al., 1994; Chapin and Shaver, 1996; Shaver et al., 1998; Bret-Harte et al., 2001). Of these, reports of $\mathrm{N}$ and $\mathrm{P}$ effects on photosynthetic and respiratory rates range from stimulation (Baddeley et al., 1994; Chapin and Shaver, 1996) to no change or inhibition (Shaver et al., 1998; Bret-Harte et al., 2001). Also, many studies on tundra vegetation use singledose nutrient addition experiments, limiting the mechanistic understanding of these processes and their response to the environment. Single-dose fertilization experiments, when not compared with multilevel, multinutrient treatments, while informative, cannot capture possible threshold limits of physiological processes by $\mathrm{N}$ or P availability that may be observed at the scale of the community (Arens et al., 2008) or leaf (Baddeley et al., 1994). Previous work by Arens et al. (2008) in dwarfshrub tundra reported a decline in GEP under higher $\mathrm{N}+\mathrm{P}$ fertilization. Leaf measurements under graded nutrient availability may also reveal species interactions with $\mathrm{N}$ and $\mathrm{P}$ and more detailed seasonal effects (Baddeley et al., 1994). However, for both leaf- and community-level measurements of carbon exchange under fertilization, the duration of nutrient addition must be considered, and comparisons across different treatment time frames may be limiting in their interpretation.

To acquire a more accurate description of carbon cycling, we need measurements of respiration in the light $\left(R_{\mathrm{L}}\right)$ in addition to photosynthesis and dark respiration, as plants experience a near 24-h photoperiod during the growing season in the carbon-rich Arctic tundra, and neglecting this measurement can lead to inaccurate estimations of leaf carbon gain. Autotrophic respiration rates are inhibited by light - a phenomena known as the Kok effect-through multiple enzymatic pathways preceding or associated with the tricarboxylic acid cycle (Budde and Randall, 1990; Hill and Bryce, 1992; Hoefnagel et al., 1998;
Tovar-Méndez et al., 2003; Tcherkez et al., 2005; Rasmusson and Escobar, 2007). Previous studies show the degree of light inhibition can be sensitive to environmental factors such as ambient $\mathrm{CO}_{2}$ concentration, growth irradiance, temperature, and water availability (Atkin et al., 2000, 2006; Hurry et al., 2005; Leegood et al., 1995; Wang et al., 2001; Shapiro et al., 2004; Pärnik et al., 2007; Tcherkez et al., 2008). However, given the multiple $\mathrm{O}_{2}$ and $\mathrm{CO}_{2}$ fluxes that occur concurrently in the light, respiration in the light cannot be measured directly. Methods have been developed to estimate $R_{\mathrm{L}}$ indirectly using stable isotopes (Weger et al., 1988; Turpin et al., 1990; Pinelli and Loreto, 2003), ${ }^{14} \mathrm{C}$ (McCashin et al., 1988; Pärnik and Keerberg, 1995; Hurry et al., 1996), and gas exchange (Kok, 1948; Laisk, 1977; Sharp et al., 1984; Brooks and Farquhar, 1985; Villar et al., 1995; Peisker and Apel, 2001). Here, the Kok (1948) method, which calculates $R_{\mathrm{L}}$ based on the extrapolation of a low-light $\mathrm{CO}_{2}$ assimilation curve is employed for this study based on its relative ease for measuring a high volume of replicates in the field.

In addition to gas exchange measurements, the characterization of pertinent leaf cellular organelles can be meaningful when addressing physiological responses to the environment. Mitochondria and chloroplasts mediate autotrophic carbon fluxes, and changes in their respective densities (based on direct counts using transmission electron microscopy) can indicate underlying adaptations, as evidenced in responses to elevated $\mathrm{CO}_{2}$ (Robertson and Leech, 1995; Robertson et al., 1995; Griffin et al., 2001; Tissue et al., 2002; Wang et al., 2004; GomezCasanovas et al., 2007), canopy position (Tissue et al., 2002), and temperature (Armstrong et al., 2006a, b). Direct count measurements of mitochondria are rare and rarer still for fieldgrown species. Moreover, to our knowledge, no study has yet assessed how organelle abundance is affected by nutrient availability, either in Arctic or non-Arctic species. Such data could provide important insights into the underlying factors responsible for nutrient-dependent changes in metabolic rates in Arctic plants.

Given the C-rich, N- and P-limited setting of the Arctic tundra, as well as the potential sensitivity of tundra vegetation to warming-mediated environmental changes, a detailed characterization of leaf- and cell-level C-cycling processes in tundra vegetation will allow for greater understanding of the current and future carbon balance in this region. To examine the physiological, subcellular, and physical responses of Arctic plant leaves to elevated soil nutrient availability, we measured variables related to foliar $\mathrm{C}$ cycling in two dominant Arctic species of contrasting growth forms, Betula nana and Eriophorum vaginatum, under increasing levels of combined $\mathrm{N}$ and $\mathrm{P}$ addition. Using multilevel fertilized plots established in 2007 at the Arctic LTER in Toolik Lake, Alaska, we measured respiration in the light and the dark, photosynthesis, mitochondrial and chloroplast densities, and related leaf traits for samples collected in July 2009. These data were analyzed to test hypotheses about leaf- and cell-level C cycling: (1) that rates of photosynthesis and respiration would increase with combined nitrogen and phosphorus availability in a coupled manner; (2) the inhibition of respiration by light would decrease with increased fertilization, as suggested by Shapiro et al. (2004); and (3) the underlying cellular ultrastructure would correspond to leaf level fluxes. To our knowledge, this study is the first to characterize rates of leaf respiration in the light in Arctic plants, as well as the first to report on nutrient-mediated changes in organelle abundance. 


\section{MATERIALS AND METHODS}

Site description and species-The study took place in July 2009 at the Arctic Long Term Ecological Research field station at Toolik Lake in the foothills region of the Brooks Range, North Slope, Alaska $\left(68^{\circ} 38^{\prime} \mathrm{N}, 149^{\circ} 43^{\prime} \mathrm{W}\right.$, elevation $760 \mathrm{~m}$ a.s.1.). Soils in this area consist of $30-50 \mathrm{~cm}$ of a peaty organic layer and a silty mineral layer, with both atop permafrost. The average growing season of this region lasts approximately $10-12 \mathrm{wk}$, beginning in early to mid-June Ambient light and temperature levels during the sampling period in late July fluctuated diurnally (Environmental Data Center Team, 2009; Fig. 1), and no large precipitation event occurred during this time.

Leaves were sampled from plots in a randomized block design (four replicate blocks) of seven fertilization treatments, created in 2007 by Gaius Shaver and colleagues on a large area of moist acidic tundra (MAT). Each year after snowmelt and prior to leaf-out, graded amounts of $\mathrm{N}$ and $\mathrm{P}$, in the form of granular ammonium nitrite and triple superphosphate, were evenly distributed on the $5 \times 20 \mathrm{~m}$ plots according to fertilization treatment. The grades of treatment increased proportionally: "CT" or " $0 \mathrm{~N}$ " (control, no fertilization), " $0.5 \mathrm{~N}$ " $\left(0.5 \mathrm{~g} \mathrm{NH}_{4} \mathrm{NO}_{3} \cdot \mathrm{m}^{-2}+0.25 \mathrm{~g} \mathrm{P} \cdot \mathrm{m}^{-2}\right) ; " 1 \mathrm{~N}$ " $\left(1 \mathrm{~g} \mathrm{NH}_{4} \mathrm{NO}_{3} \cdot \mathrm{m}^{-2}+0.5 \mathrm{~g} \mathrm{P} \cdot \mathrm{m}^{-2}\right)$ " $2 \mathrm{~N} "\left(2 \mathrm{~g} \mathrm{NH}_{4} \mathrm{NO}_{3} \cdot \mathrm{m}^{-2}+1 \mathrm{~g} \mathrm{P} \cdot \mathrm{m}^{-2}\right)$; " $5 \mathrm{~N}$ " $\left(5 \mathrm{~g} \mathrm{NaNO}_{3} \cdot \mathrm{m}^{-2}+2.5 \mathrm{~g} \mathrm{P} \cdot \mathrm{m}^{-2}\right)$; and "10N" (10 $\left.\mathrm{g} \mathrm{NH}_{4} \mathrm{NO}_{3} \cdot \mathrm{m}^{-2}+5 \mathrm{~g} \mathrm{P} \cdot \mathrm{m}^{-2}\right)$. The experimental plots also included "nitrate-only" (5 $\left.\mathrm{g} \mathrm{NaNO}_{3} \cdot \mathrm{m}^{-2}+2.5 \mathrm{~g} \mathrm{P} \cdot \mathrm{m}^{-2}\right)$ and "ammonium-only" (5 g $\mathrm{NH}_{4} \mathrm{Cl} \cdot \mathrm{m}^{-2}+2.5 \mathrm{~g} \mathrm{P} \cdot \mathrm{m}^{-2}$ ) plots. For this study, leaves were sampled from the control $(0 \mathrm{~N}), 5 \mathrm{~N}$, and $10 \mathrm{~N}$ plots only. It should be noted that these treatmen levels, while denoted as $0 \mathrm{~N}, 5 \mathrm{~N}$, and $10 \mathrm{~N}$, represent a combined dosage of nitrogen and phosphorus.

The species selected for this study represent the dominant tundra vegetation of the North Slope. Eriophorum vaginatum (cottongrass) is an evergreen tussock sedge, whose range spans the Arctic tundra and subboreal latitudes. Betula nana (dwarf birch) is a deciduous shrub, whose distribution covers Arctic, subArctic, and alpine regions. Physiological measurements were made on fully illuminated leaves sampled from the top of the tundra canopy in July 2009. Care was taken to ensure a sampling of fully expanded leaves of a similar size and age for both species.

Foliar gas exchange- $\mathrm{CO}_{2}$ assimilation rate as a response of light was measured under ambient (400 ppm) $\mathrm{CO}_{2}$ concentration using a Li-Cor 6400xt infra-red gas analyzer (IRGA) (Li-Cor, Lincoln, Nebraska, USA). Four replicate measurements were made for each species under the three fertilization growth conditions corresponding to the four replicate blocks of the experimental plots. Cuvette block temperature was set to $20^{\circ} \mathrm{C}$ for all measurements to control for leaf temperature effects and is representative of temperatures experienced by leaves during the measurement period (Fig. 1). Relative humidity inside the leaf chamber was maintained between 30-60\% during measurements, and leaf vapor pressure deficit average was $0.709 \pm 0.075$ (SE) across all treatments. Leaves were enclosed in the cuvette at high light conditions to acclimate prior to measurement. Measurements of $\mathrm{CO}_{2}$ assimilation were recorded at photosynthetic photon flux density (PPFD) of 1500, 1200, 800, 400, 200 , and $100 \mu \mathrm{mol} \cdot \mathrm{m}^{-2} \cdot \mathrm{s}^{-1}$ and then by every $5 \mu \mathrm{mol} \cdot \mathrm{m}^{-2} \cdot \mathrm{s}^{-1}$ decreasing to $0 \mu \mathrm{mol} \cdot \mathrm{m}^{-2} \cdot \mathrm{s}^{-1}$. This range of light levels fully encompasses the light environment experienced by both species in their natural environment (Fig. 1). To estimate theoretically maximal light-saturated photosynthetic rate $\left(A_{\max }\right)$, we used curve-fitting software (Excel Solver version 12.0.4518, Microsoft, Redmond, Washington, USA) and a rectangular hyperbolic function. Dark respiration $\left(R_{\mathrm{D}}\right)$ was measured as the $\mathrm{CO}_{2}$ efflux at zero irradiance. Photosynthetic rates at PPFD of $900 \mu \mathrm{mol} \cdot \mathrm{m}^{-2} \cdot \mathrm{s}^{-1}\left(A_{900}\right)$ were also measured, as this light level is representative of the average light environment during sampling and measurement times (Fig. 1). For gas exchange, all leaves sampled were cut in the field, recut while

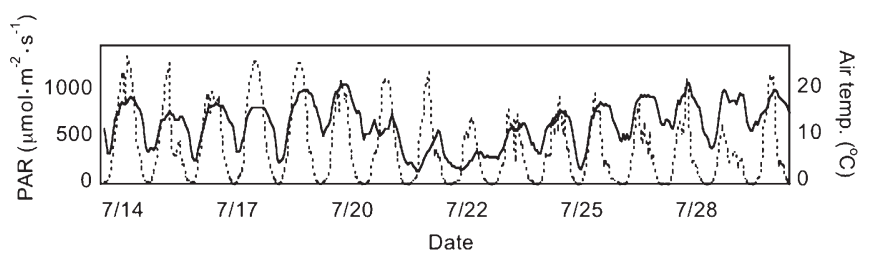

Fig. 1. Light (PAR; dashed line) and temperature (solid line) during the sampling period in July 2009, measured nearby within $100 \mathrm{~m}$ of the treatment plots at Toolik Lake, Alaska. PAR, photosynthetically active radiation. submerged under water, and measured inside in the laboratory. Previous experiments on these species showed no difference in rates of gas exchange and stomatal conductance between field-measured and laboratory-measured, cut leaves (K. L. Griffin, unpublished data). Multiple $(N \cong 10) E$. vaginatum leaves were laid across the base of the cuvette to cover the $6-\mathrm{cm}^{2}$ area. Betula leaves, which were smaller than the $6-\mathrm{cm}^{2}$ cuvette area, were measured for leaf area after IRGA measurement and assimilation values were calibrated to that area for calculations. Values of photosynthesis are expressed on an area and mass basis Photosynthetic N-use efficiency (PNUE) is expressed as $A_{\max }$ per milligram N.

Quantifying respiration in the light using the Kok effect-Respiration in the light $\left(R_{\mathrm{L}}\right)$ was indirectly measured using the Kok (1948) method, which plots $\mathrm{CO}_{2}$ assimilation as a response of light at low PPFD $\left(<100 \mu \mathrm{mol} \cdot \mathrm{m}^{-2} \cdot \mathrm{s}^{-1}\right)$ Using the light curves described earlier, the low light points were analyzed using Excel Solver version 12.0.4518 to distinguish and fit two lines, one above and one below the "breakpoint" that occurs under low-light measurements (Shapiro et al., 2004). Where the line extrapolated from points above the breakpoint intersects the $y$-axis is considered $R_{\mathrm{L}}$. The line fitted from points below the breakpoint intersects the $y$-axis at the $R_{\mathrm{D}}$ value, where PPFD $=0 \mu \mathrm{mol} \cdot \mathrm{m}^{-2} \cdot \mathrm{s}^{-1}$. Respiration in the light was estimated after correcting for changes in internal $\mathrm{CO}_{2}$ concentration according to Kirschbaum and Farquhar (1987), as described in Ayub et al. (2011). This correction accounted for changes in $\mathrm{CO}_{2}$ concentration at the site of carboxylation that occur under decreasing light. The degree of inhibition of respiration by light is expressed as $I_{\mathrm{RL}}=1-\left(R_{\mathrm{L}} / R_{\mathrm{D}}\right)$. These measurements were taken at a relative humidity of approximately $40-60 \%$, and $\mathrm{CO}_{2}$ concentration of $400 \mathrm{ppm}$. Potential diffusion in and out of the cuvette was accounted for, as was diffusion through the gasket, according to corrections presented in the LiCor 6400 Instructional Manual.

Measurement of $\mathrm{O}_{2}$ consumption of leaves-Oxygen consumption by leaf tissue was measured using a Clark-type liquid phase oxygen electrode (Rank Brothers, Cambridge, UK; Hansatech Instruments, Norfolk, UK). Prior to measurement in the electrode, leaf tissue was sliced into small segments with a razor in $20 \mathrm{mmol} / \mathrm{L}$ MES buffer $(\mathrm{pH}=6.0)$ and incubated in the dark for approximately $30 \mathrm{~min}$. For uncoupled rates of oxygen consumption, $20 \mu \mathrm{mol} / \mathrm{L}$ carbonylcyanide $m$-chlorophenylhydrazone was added to the incubation and measurement buffers to achieve uncoupled (near maximal) rates of mitochondrial respiration. The electrode cuvette contained $2 \mathrm{~mL}$ of the same MES buffer for measurements, which were conducted at $20^{\circ} \mathrm{C}$. The depletion of oxygen was recorded over $\sim 5 \mathrm{~min}$, and rates were calculated on a dry mass basis. Two replicates were measured for each species under each growth condition per replicate block for a total $N=8$.

Organelle ultrastructure-Leaves were collected in late July and then fixed at $5^{\circ} \mathrm{C}$ in buffered glutaraldehyde $(2 \% \mathrm{w} / \mathrm{v}$ in $0.05 \mathrm{~mol} / \mathrm{L}$ potassium phosphate buffer), placed in sealed glass $20 \mathrm{~mL}$ vials, and transported in insulated containers from Alaska to Lamont-Doherty Earth Observatory in Palisades, New York, USA. Samples were postfixed in $2 \%(\mathrm{w} / \mathrm{v})$ phosphate-buffered osmium tetroxide, dehydrated in graded acetone series, embedded in catalyzed epon (TAAB resin, Energy Beam Sciences, Agawan, Massachusetts, USA), and polymerized at $65^{\circ} \mathrm{C}$. Ultrathin sections were obtained using a Porter-Blum MT-2 ultramicrotome, collected on uncoated copper grids, stained with Reynold's lead citrate, and examined with a Philips 201 transmission electron microscope (Einthoven, Netherlands) operated at $60 \mathrm{kV}$ accelerating voltage. The total number of mitochondria and chloroplasts were counted per cell section $(N=45$ per species and treatment combination), and measured for size $(N=30$, from a subset of cells measured for density), as described in Griffin et al. (2001). Each cell was measured for area, and mitochondrial density and chloroplast density (number per unit cell area, not including cell walls) were calculated.

Physical leaf traits and foliar nutrients-All leaf samples used for gas exchange measurements were also measured for leaf area using a flatbed scanner and computer with the WinRhizo program (Regent Instruments, Quebec City, Quebec, Canada). After the area was measured, leaf samples were dried in an oven at $60^{\circ} \mathrm{C}$ for a minimum of $2 \mathrm{~d}$ before mass was determined. After transport to New York, these samples were ground, weighed, and packaged for elemental analysis to determine [CHN] (2400 Series II, Perkin-Elmer, Boston, Massachusetts, USA). Remaining ground leaf samples were bulked by replicate block $(N=4)$ and sent to the North Carolina State University Environmental and Agricultural Testing Service (Raleigh, North Carolina, USA) for analysis by wet digestion to determine total phosphorus concentration. 
Statistical design and analysis-Rates of photosynthesis and respiration, TEM organelle data, and leaf characteristics were analyzed using a two-way analysis of variance (ANOVA) with species and fertilization treatment as factors. Differences between fertilization levels were determined with post hoc Tukey's test. All data obtained from the experiment are expressed as means \pm SE. All analyses used the statistical programming software R version 2.11.1 (R Development Core Team, 2010).

\section{RESULTS}

Leaf nutrients and physical leaf traits-Leaf nitrogen concentration exhibited differences between species $(P<0.001$, $\left.F_{1,22}=112.70\right)$, treatments $\left(P<0.001, F_{2,9}=33.28\right)$, and interaction effects were also found to be significant $\left(P<0.005, F_{2,18}=\right.$ 10.113). In leaves of E. vaginatum, $\mathrm{N}$ concentration showed a general increasing trend from $0 \mathrm{~N}$ and $5 \mathrm{~N}$ to $10 \mathrm{~N}$, and in leaves of B. nana, this trend was significant $(P<0.001$, Fig. 2). Highest

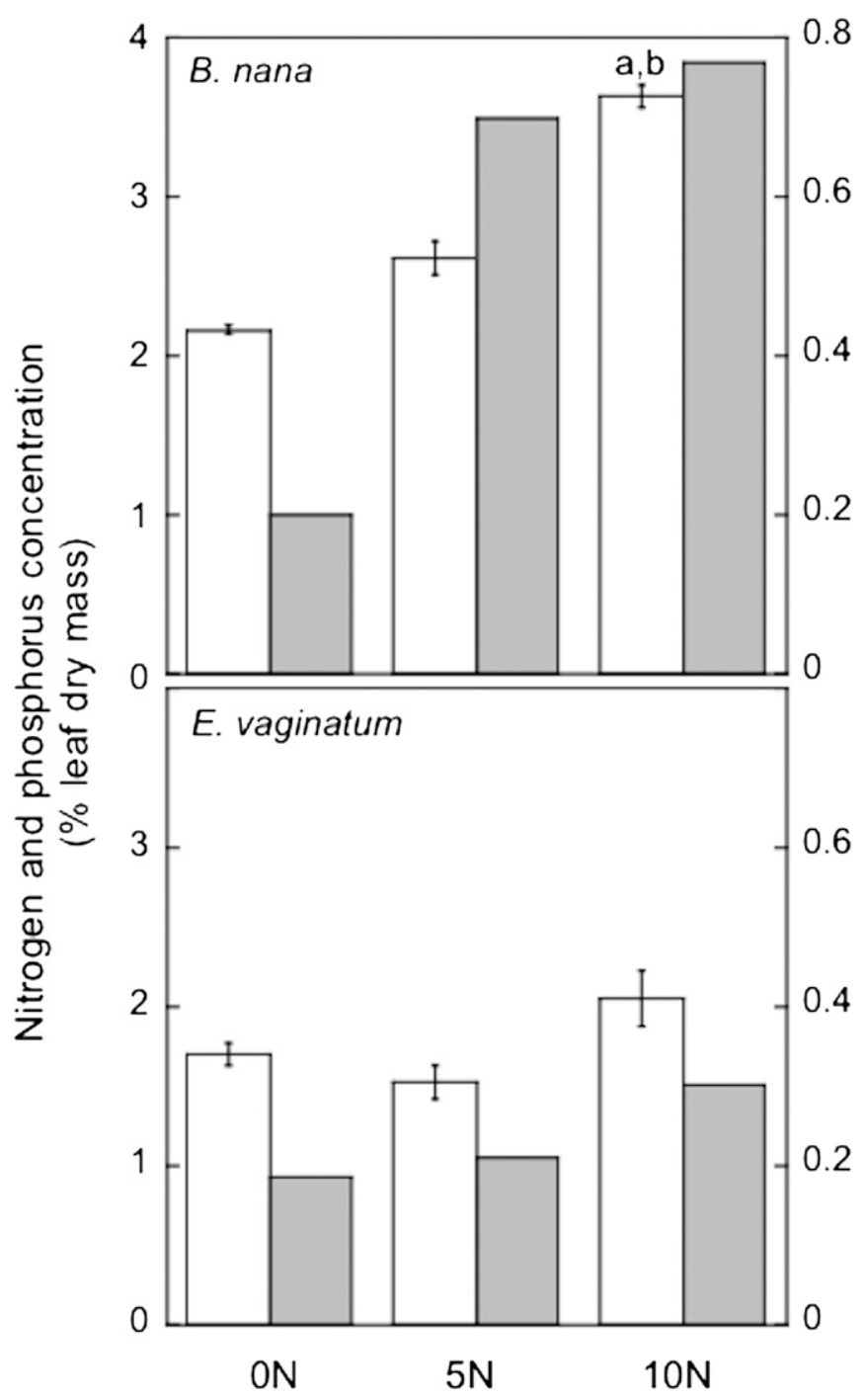

Fig. 2. Leaf nitrogen (unshaded, left axis) and phosphorus (shaded, right axis) concentration of Betula nana and Eriophorum vaginatum grown under the three fertilization treatments $(N=4)$. Values are means \pm SEM, with alphabetic notation signifying significance at $P<0.05$ between the treatment levels. Limited sample size prohibited error to be calculated for phosphorus values.
$\mathrm{N}$ concentration for both species was measured in leaves grown under the $10 \mathrm{~N}$ treatment (Fig. 2). Leaf carbon (C) concentration differed between species $\left(P<0.05, F_{1,22}=6.411\right)$, with $B$. nana higher than $E$. vaginatum at all treatment levels, though there was no significant difference across treatments. Leaf $\mathrm{C}$ concentration was greatest at the $5 \mathrm{~N}$ treatment level for both species. The ratio of $\mathrm{C}$ to $\mathrm{N}(\mathrm{C}: \mathrm{N})$ differed between species $(P<0.001$, $\left.F_{1,22}=88.80\right)$, across treatments $\left(P<0.001, F_{2,9}=26.23\right)$, and species-treatment interactions $\left(P<0.05, F_{2,18}=5.30\right)$. E. vaginatum had higher $\mathrm{C}: \mathrm{N}$ values at all treatment levels, with the greatest value observed at the $5 \mathrm{~N}$ treatment level $(30.33 \pm 3.77)$. Values for $\mathrm{C}: \mathrm{N}$ decreased in $B$. nana with increasing fertilization $(P<0.01)$. Leaf phosphorus values (Fig. 2) were limited statistically due to the small number of replicates, though the highest values for both species were recorded in leaves grown under the $10 \mathrm{~N}$ treatment.

Specific leaf area (SLA), a measurement of leaf area per unit mass, differed at the species level $\left(P<0.001, F_{1,22}=29.74\right)$, and from the $0 \mathrm{~N}$ to $10 \mathrm{~N}$ treatment in $E$. vaginatum $(P<0.05$, Fig. 3). For both species, the highest mean SLA leaves were observed at the $10 \mathrm{~N}$ treatment level, and values for $B$. nana were higher than E. vaginatum at each treatment level, though structural differences due to leaf type likely drive these differences. Leaf dry matter content (DMC) also differed between species $\left(P<0.01, F_{1,22}=8.67\right)$ and treatment $\left(P<0.05, F_{2,9}=\right.$ 4.54). Greater DMC was found in B. nana, and in both species, DMC decreased with increasing fertilization. Values of fresh mass per area (FMA) differed highly between species $(P<0.0001$, $\left.F_{1,22}=749.74\right)$, and nonsignificant fertilization and interaction effects were observed; $B$. nana increased slightly under nutrient addition, and FMA of E. vaginatum decreased by nearly $20 \%$ between the $0 \mathrm{~N}$ to $10 \mathrm{~N}$ levels.

Foliar gas exchange across a fertilization gradient-Areabased rates of maximal photosynthesis $\left(A_{\max }\right)$ displayed no significant differences between the species or across the $\mathrm{N}$ and $\mathrm{P}$ treatment gradient, though mass-based rates of maximal photosynthesis were greater in $B$. nana $(P<0.05)$, and interaction effects were observed $(P<0.01$; Table 1$)$. The highest rates of carbon assimilation were observed under the $5 \mathrm{~N}$ treatment of $B$. nana and under the $10 \mathrm{~N}$ treatment of $E$. vaginatum, whereas the lowest rates were observed at $0 \mathrm{~N}$ in $B$. nana and $5 \mathrm{~N}$ for E. vaginatum (Table 2). Area- and mass-based rates of $A_{900}$ differed in species-treatment interaction (Table 1), following the same trends as observed in $A_{\max }$ (Table 2). $A_{\max }$ displayed no clear, cross-taxa trend when expressed as a response to leaf $\mathrm{N}$ concentration (Fig. 4). PNUE exhibited treatment effects $(P<0.01)$ and was higher in $E$. vaginatum $(P<0.001)$. Greatest PNUE was observed under the $5 \mathrm{~N}$ treatment in $B$. nana, and PNUE decreased under higher levels of fertilization in E. vaginatum (Fig. 5).

Area- and mass-based mitochondrial dark respiration rates were greater in $B$. nana than in $E$. vaginatum $(P<0.001$ and 0.01 , respectively), but displayed no treatment or interaction effects (Table 1). Highest area-based rates of $R_{\mathrm{D}}$ were observed under the $10 \mathrm{~N}$ treatment level for both species (B. nana: $4.5 \pm 1.02 \mu \mathrm{mol} \mathrm{CO}_{2} \cdot \mathrm{m}^{-2} \cdot \mathrm{s}^{-1} ;$ E. vaginatum: $1.8 \pm 0.25 \mu \mathrm{mol}$ $\mathrm{CO}_{2} \cdot \mathrm{m}^{-2} \cdot \mathrm{s}^{-1}$ ), and $B$. nana displayed a general increasing trend in rates of $R_{\mathrm{D}}$ across the fertilization gradient on an area and mass basis (Fig. 6A, 6C). When expressed on a mass basis, respiration decreased under increasing fertilization in E. vaginatum (Fig. 6D). A general cross-taxa increase in $R_{\mathrm{D}}$ was observed when expressed as a response to average leaf $\mathrm{N}$ concentration 


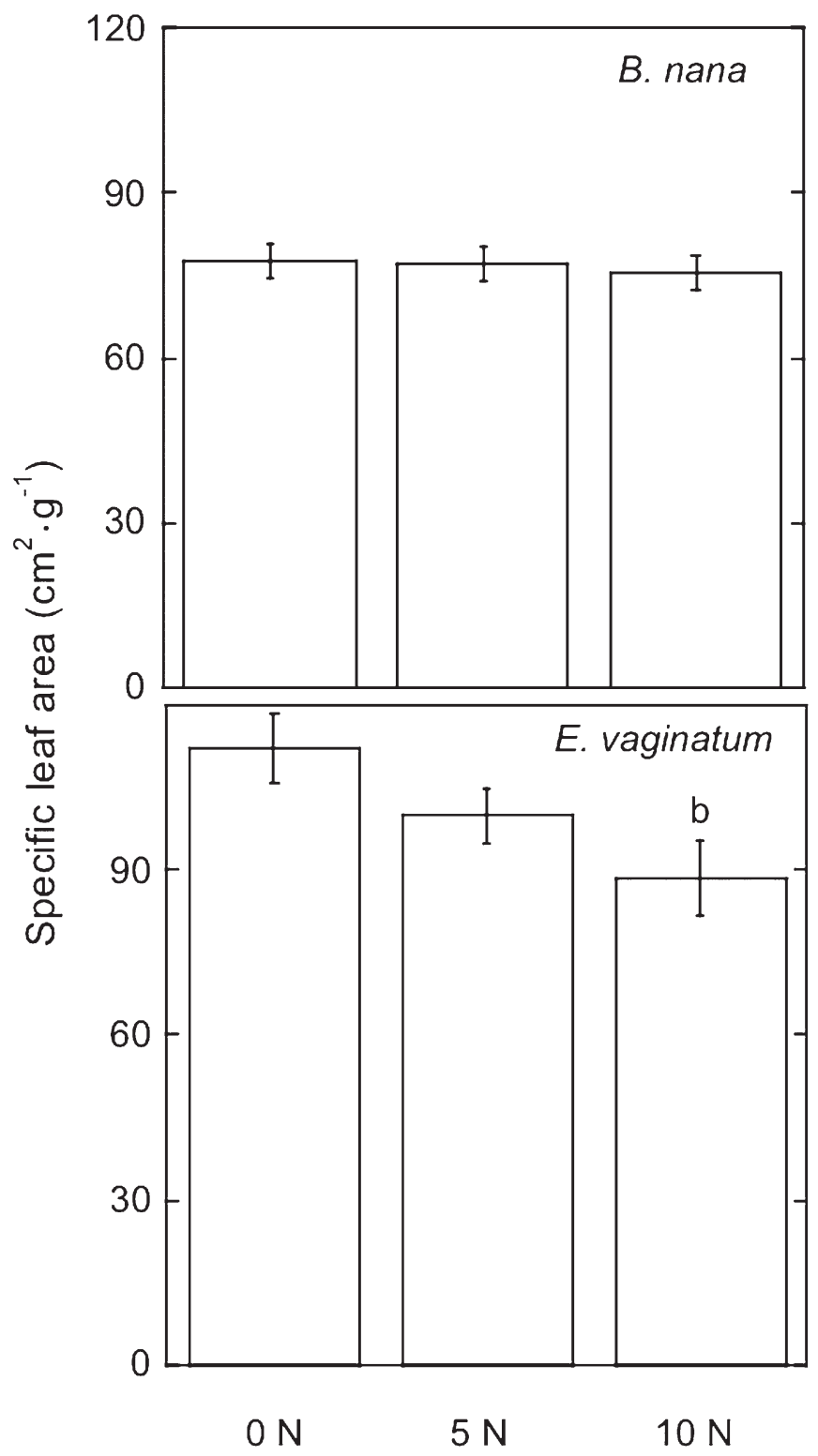

Fig. 3. Specific leaf area (SLA) of Betula nana and Eriophorum vaginatum under the three treatment levels $(N=4)$. Values are means \pm SEM and alphabetic notation signifying significance at $P<0.05$ between the treatment levels.

(Fig. 4). Respiration in the light also differed by species $(P<$ 0.001 ) with $B$. nana exhibiting higher rates at all fertilization levels (Fig. 6). Area- and mass-based rates of $R_{\mathrm{L}}$ did not differ significantly, but displayed an increasing trend in $B$. nana from the $0 \mathrm{~N}$ to $10 \mathrm{~N}$ level (Fig. 6A, 6C). Overall, average $R_{\mathrm{L}}$ increases with average leaf $\mathrm{N}$ concentration, though this relationship is stronger in B. nana (Fig. 4).

The net foliar carbon exchange, a ratio of photosynthetic to respiratory rates, was greater in E.vaginatum for both measurements of respiration $(P<0.001$, Tables 1,2$)$. E. vaginatum had a higher net exchange than $B$. nana at the $0 \mathrm{~N}$ and $10 \mathrm{~N}$ levels for $A: R_{\mathrm{D}}$, but not $A: R_{\mathrm{L}}$. No difference was observed across fertilization treatments for either species for $A: R_{\mathrm{D}}$ and $A: R_{\mathrm{L}}$, though an interaction effect between species and treatment level was
TABLE 1. Two-way ANOVA results for photosynthetic and respiratory variables comparing Betula nana and Eriophorum vaginatum (species), nitrogen and phosphorus fertilization treatment levels (NP), and interaction effects $($ species $\times \mathrm{NP})$.

\begin{tabular}{|c|c|c|c|c|c|c|}
\hline \multirow[b]{2}{*}{ Variable } & \multicolumn{2}{|c|}{ Species $(\mathrm{df}=1)$} & \multicolumn{2}{|c|}{$\mathrm{NP}(\mathrm{df}=2)$} & \multicolumn{2}{|c|}{$\begin{array}{c}\text { Species x NP } \\
(\mathrm{df}=2)\end{array}$} \\
\hline & $F$ - ratio & $P$ & $F$ - ratio & $P$ & $F$ - ratio & $P$ \\
\hline$A_{\max (\text { area) }}$ & 0.242 & 0.629 & 1.712 & 0.210 & 7.045 & $* *$ \\
\hline$A_{\max (\operatorname{mass})}$ & 5.544 & * & 1.018 & 0.382 & 7.970 & $* *$ \\
\hline$A_{900 \text { (area) }}$ & 1.006 & 0.330 & 3.447 & 0.055 & 9.692 & $* *$ \\
\hline$A_{900 \text { (mass) }}$ & 3.394 & 0.083 & 2.788 & 0.090 & 9.746 & $* *$ \\
\hline$R_{\mathrm{D} \text { (area) }}$ & 28.471 & $* * *$ & 1.826 & 0.191 & 1.928 & 0.176 \\
\hline$R_{\mathrm{D} \text { (mass) }}$ & 13.317 & $* *$ & 0.495 & 0.618 & 3.206 & 0.066 \\
\hline$R_{\mathrm{L} \text { (area) }}$ & 18.170 & $* * *$ & 2.412 & 0.120 & 1.893 & 0.181 \\
\hline$R_{\mathrm{L} \text { (mass) }}$ & 11.304 & ** & 1.421 & 0.269 & 2.591 & 0.104 \\
\hline$I_{\mathrm{RL}}$ & 2.160 & 0.160 & 1.192 & 0.328 & 0.186 & 0.832 \\
\hline$A: R_{\mathrm{D}}$ & 46.112 & $* * *$ & 0.418 & 0.665 & 3.880 & $* *$ \\
\hline$A: R_{\mathrm{L}}$ & 16.954 & $* * *$ & 0.246 & 0.785 & 0.607 & 0.556 \\
\hline
\end{tabular}

Notes: Variables analyzed include area- and mass-based photosynthesis rates $\left(A_{\max } ; A_{900}\right)$, dark respiration $\left(R_{\mathrm{D}}\right)$, respiration in the light $\left(R_{\mathrm{L}}\right)$, degree of respiratory inhibition by light $\left(I_{\mathrm{RL}}\right)$, ratios of photosynthesis to respiration rates $\left(A: R_{\mathrm{D}}\right.$ and $\left.A: R_{\mathrm{L}}\right)$, coupled respiration via oxygen consumption $\left(R_{\mathrm{C}}\right)$, and uncoupled respiration via oxygen consumption $\left(R_{\mathrm{UC}}\right)$. For $A_{\mathrm{Max}}, R_{\mathrm{D}}, R_{\mathrm{L}}$, $I_{\mathrm{RL}}, A: R_{\mathrm{D}}$, and $A: R_{\mathrm{L}}, N=3-4$ for $B$. nana and $N=4$ for $E$. vaginatum. Stars represent significance as follows: $* P<0.05$, ** $P<0.01$, *** $P<0.001$.

observed in $A: R_{\mathrm{D}}(P<0.01$, Table 1$)$. The highest mean net exchange occurred in leaves grown in the $5 \mathrm{~N}$ treatment plots for $B$. nana and in the $10 \mathrm{~N}$ treatment plots for $E$. vaginatum (Table 2). Conversely, the lowest mean net exchange (considering both $R_{\mathrm{D}}$ and $R_{\mathrm{L}}$ ) occurred in leaves from the highest fertilization treatment plots for $B$. nana and the $5 \mathrm{~N}$ treatment plots for $E$. vaginatum (Table 2).

Measurements of coupled and uncoupled rates of dark respiration differed between species $\left(P<0.01, F_{1,48}=10.02\right)$, but not in treatment level or interaction effects. The highest coupled rates of respiration were found in leaves grown in the $5 \mathrm{~N}$ treatment plots for $B$. nana and the $10 \mathrm{~N}$ treatment plot for $E$. vaginatum (Table 3 ), whereas the highest uncoupled rates were found in leaves grown under the $10 \mathrm{~N}$ treatment in $B$. nana and the $0 \mathrm{~N}$ treatment in $E$. vaginatum. The effect of the uncoupling agent $\mathrm{CCCP}$ varied in elevation in oxygen consumption rates (Table 3), with a mean stimulating effect of $13 \pm 4 \%$ across both species and all treatments.

Light inhibition of respiration-Respiration was inhibited by light among all replicates $\left(P<0.001, F_{1,21}=359.15\right)$, though species and treatment differences in the inhibition of respiration by light $\left(I_{\mathrm{RL}}\right)$ were not detected (Table 1). However, in both species, $I_{\mathrm{RL}}$ showed a decreasing trend with higher levels of $\mathrm{N}$ and $\mathrm{P}$ fertilization. The degree of the Kok effect ranged from $12-62 \%$ with a mean of $33.5 \pm 2.7 \%$ across both species and all treatments. Though not significant, $B$. nana exhibited less light inhibition than $E$. vaginatum at all three treatment levels. Across both species, when expressed as a response to leaf $\mathrm{N}$ concentration, $I_{\mathrm{RL}}$ decreases with higher leaf $\mathrm{N}$ concentration (Fig. 4).

Organelle ultrastructural characteristics-Chloroplast and mitochondrial densities and sizes were influenced by fertilization treatments for both species (Fig. 7, Table 4). Chloroplast density exhibited treatment $(P<0.001)$, but not species or interaction effects (Table 4). Within species, B. nana chloroplast density increased from $0 \mathrm{~N}$ and $5 \mathrm{~N}$ to the $10 \mathrm{~N}$ treatment level 
TABLE 2. Mean $( \pm \mathrm{SE})$ photosynthetic rates of Betula nana and Eriophorum vaginatum under fertilization treatments, including maximal photosynthesis $\left(A_{\max }\right)$ and photosynthesis at photosynthetic photon flux density of $900 \mu \mathrm{mol} \cdot \mathrm{m}^{-2} \cdot \mathrm{s}^{-1}\left(A_{900}\right)$, on an area and mass basis $(N=4)$. Values for the ratio of photosynthesis to respiration in the dark $\left(A: R_{\mathrm{D}}\right)$ and light $\left(A: R_{\mathrm{L}}\right)$ are also shown.

\begin{tabular}{|c|c|c|c|c|c|c|}
\hline Treatment & $A_{\max (\text { area) }}\left(\mu \mathrm{mol} \mathrm{CO} \mathrm{CO}_{2} \cdot \mathrm{m}^{-2} \cdot \mathrm{s}^{-1}\right)$ & $A_{900 \text { (area) }}\left(\mu \mathrm{mol} \mathrm{CO} \cdot \mathrm{m}^{-2} \cdot \mathrm{s}^{-1}\right)$ & $A_{\max (\operatorname{mas})}\left(\mathrm{nmol} \mathrm{CO}{ }_{2} \cdot \mathrm{g}^{-1} \cdot \mathrm{s}^{-1}\right)$ & $A_{900 \text { (mass) }}\left(\mathrm{nmol} \mathrm{CO}{ }_{2} \cdot \mathrm{g}^{-1} \cdot \mathrm{s}^{-1}\right)$ & $A: R_{\mathrm{D}}$ & $A: R_{\mathrm{L}}$ \\
\hline $0 \mathrm{~N}$ & $14.4 \pm 1.18$ & $9.4 \pm 0.80$ & $111.3 \pm 8.77$ & $73.0 \pm 6.53$ & $5.2 \pm 0.63$ & $8.15 \pm 1.12$ \\
\hline $5 \mathrm{~N}$ & $24.5 \pm 3.26$ & $17.6 \pm 2.30$ & $189.9 \pm 28.40$ & $136.9 \pm 20.12$ & $7.1 \pm 0.62$ & $10.2 \pm 1.68$ \\
\hline \multicolumn{7}{|c|}{ E. vaginatum } \\
\hline $0 \mathrm{~N}$ & $18.0 \pm 0.83$ & $11.8 \pm 0.51$ & $202.6 \pm 17.73$ & $133.2 \pm 11.37$ & $10.2 \pm 0.81$ & $17.4 \pm 1.33$ \\
\hline $5 \mathrm{~N}$ & $15.2 \pm 0.93$ & $10.1 \pm 0.33$ & $150.8 \pm 4.61$ & $100.6 \pm 3.22$ & $9.4 \pm 0.90$ & $16.7 \pm 4.77$ \\
\hline $10 \mathrm{~N}$ & $19.1 \pm 2.64$ & $12.4 \pm 1.48$ & $170.6 \pm 17.78$ & $107.2 \pm 9.38$ & $10.8 \pm 1.15$ & $17.6 \pm 3.30$ \\
\hline
\end{tabular}

(both $P<0.05$ ), and in E. vaginatum it increased from $0 \mathrm{~N}$ to $10 \mathrm{~N}(P<0.01)$. Chloroplast size differed among effects based on species, treatment, and species-treatment interaction (all $P<$ 0.001 , Table 4). The largest mean chloroplast sizes were $3.3 \mu \mathrm{m}^{-2}$ in $B$. nana under no fertilization treatment and $3.1 \mu^{-2}$ in E. vaginatum under $10 \mathrm{~N}$ treatment. E. vaginatum exhibited a general, though not significant, decreasing trend in chloroplast size from $0 \mathrm{~N}$ to $10 \mathrm{~N}$, while $B$. nana increased from $0 \mathrm{~N}$ to $5 \mathrm{~N}$ and $5 \mathrm{~N}$ to $10 \mathrm{~N}$. The mean total chloroplast area per cell increased $35 \%$ and $28 \%$ from $0 \mathrm{~N}$ and $5 \mathrm{~N}$ to $10 \mathrm{~N}$ respectively, in $E$. vaginatum, whereas the same measure in $B$. nana increased over $500 \%$ from $0 \mathrm{~N}$ to $10 \mathrm{~N}$ (Fig. 8A, 8D).

Mitochondrial density differed by species $(P<0.001)$, fertilization treatment $(P<0.001)$, and the interaction effect $(P<$ 0.05 , Table 4$)$. Mitochondrial density was greatest for both species at the $5 \mathrm{~N}$ treatment level (B. nana: 0.18 mitochondria. $\mu \mathrm{m}^{-2}$ cell area; $E$. vaginatum: 0.11 mitochondria $\cdot \mu \mathrm{m}^{-2}$ cell area), and higher densities were observed in B. nana at all treatment levels. Mitochondrial size was influenced by species, fertilization level, and the interaction $(P<0.01,0.001$, and 0.001 , respectively, Table 4). Although no significant increase was observed between the $0 \mathrm{~N}$ and $5 \mathrm{~N}$ treatment in, mean mitochondrial size increased under $10 \mathrm{~N}$ in E. vaginatum $(P<0.001)$. Betula nana did not show a similar increasing trend in mitochondrial size under fertilization. The largest mitochondria were observed in leaf sections sampled from the $10 \mathrm{~N}$ treatment plot for $E$. vaginatum $\left(0.24 \mu^{-2}\right)$, and in leaf sections from the control plots for $B$. nana $\left(0.21 \mu^{-2}\right)$. The mean total mitochondrial area per cell increased $267 \%$ in E. vaginatum, and $27 \%$ in B. nana as fertilization increased from $0 \mathrm{~N}$ to $10 \mathrm{~N}$ (Fig. 8B, 8E). The ratio of total average chloroplast area to total average mitochondria area per cell was greatest under the $10 \mathrm{~N}$ treatment in B. nana (Fig. 8C) and under the control treatment in E. vaginatum (Fig. 8F).

\section{DISCUSSION}

This study presents data on the responses of photosynthesis and respiration under increasing fertilization levels in two dominant Arctic tundra species. We also report, for the first time, measurements of the light inhibition of respiration in these species, and the effects of increased $\mathrm{N}$ and $\mathrm{P}$ availability on this effect, as well as on mitochondria and chloroplast density and abundance. We evaluated these leaf-level and cellular fine structure responses to increased $\mathrm{N}$ and $\mathrm{P}$ fertilization in arctic tundra plants with the hypothesis that gas exchange rates, related chloroplast and mitochondria size and density per unit cell area, and leaf traits will respond in a coupled manner.
Decoupled rates of gas exchange under nutrient additionThe photosynthetic rates $\left(A_{\max }\right.$ and $\left.A_{900}\right)$ of both $B$. nana and $E$. vaginatum diverged from a direct trend in response to $\mathrm{N}$ and $\mathrm{P}$ fertilization and did not correlate with leaf $\mathrm{N}$ concentration. Previous work by Chapin and Shaver (1996), using the same fertilization treatment as the $10 \mathrm{~N}$ level for this study for approximately the same duration $(\sim 3 \mathrm{yr})$, found a significant increase in leaf-level photosynthesis under nutrient addition for $B$. nana and $E$. vaginatum that was also observed in two other tundra species. In contrast, Bret-Harte et al. (2001) observed a decrease in leaf-level photosynthetic rate in B. nana grown for $8 \mathrm{yr}$ under the same fertilization application as Chapin and Shaver (1996), suggesting either potential long-term acclimation or diminishing impact of increased soil nutrient availability. These examples suggest an influence of treatment duration on gas exchange measurements in these species. A similar response was documented in another tussock sedge, Eriophorum angustifolium, under the same treatment application for $\sim 5 \mathrm{yr}-$ photosynthesis decreased, while rates of respiration were unaffected by fertilization (Shaver et al., 1998). Another mechanistic explanation for this response may be $\mathrm{N}$ saturation, where increased leaf $\mathrm{N}$ is not accompanied by a coupled increased in photosynthetic capacity (Aber et al., 1989; Bauer et al., 2004), and this phenomenon has been documented in tundra vegetation at the community scale (Arens et al., 2008). Further, both species in this study exhibit the lowest PNUE at the highest fertilization treatment (Fig. 5) and highest leaf N, suggesting the allocation of $\mathrm{N}$ to nonphotosynthetic proteins, such as nitrate storage or cell wall material (Takashima et al., 2004). This trend is underscored by the tandem decrease in SLA under the $10 \mathrm{~N}$ treatment in the evergreen E. vaginatum (Fig. 3). Seasonal and developmental timing, which can produce interactive effects on gas exchange in tundra vegetation under nutrient addition, may also explain differences in measured responses across studies (Atkin and Cummins, 1994; Baddeley et al., 1994; Illeris and Jonasson, 1999). Environmental heterogeneity across measurement years (Boelman et al., 2005; Arens et al., 2008) may further complicate cross-study comparisons of nutrient influences on carbon cycling. The decoupling of carbon assimilation with leaf nitrogen and fertilization treatment and the pronounced species differences emphasize the need to evaluate the broader dynamics of leaf carbon balance when considering the response of Arctic ecosystems to environmental change.

Respiration generally responded more directly to fertilization in $B$. nana than in $E$. vaginatum for both $R_{L}$ and $R_{D}$, underscored by differences in leaf concentrations of $\mathrm{N}$ and $\mathrm{P}$ (Figs. 2, 4). These differences may be explained by functional differences between the species, such as (1) their source of $\mathrm{N}$ acquisition$B$. nana forms ectomyccorhizal associations, and $E$. vaginatum 

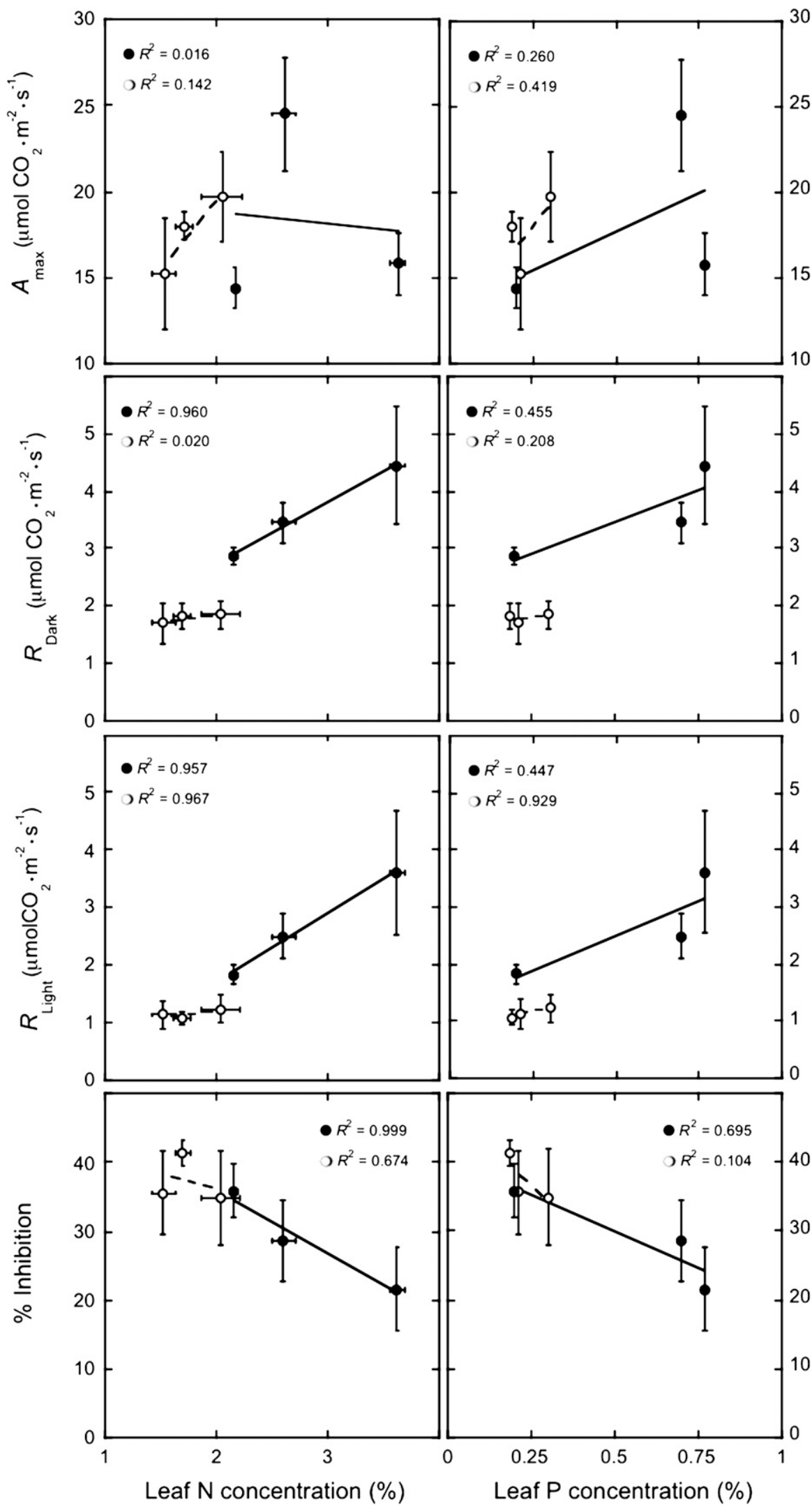

Fig. 4. Rates of foliar $\mathrm{CO}_{2}$ exchange, including maximum photosynthesis $\left(A_{\max }\right)$, dark respiration $\left(R_{\text {Dark }}\right)$, respiration in the light $\left(R_{\text {Light }}\right)$, and degree of inhibition of respiration by light (\% Inhibition) in Betula nana (filled) and Eriophorum vaginatum (unfilled) as a response of leaf $\mathrm{N}$ and $\mathrm{P}$ concentrations $(N=4)$. Values are means \pm SEM and adjusted $R^{2}$. 


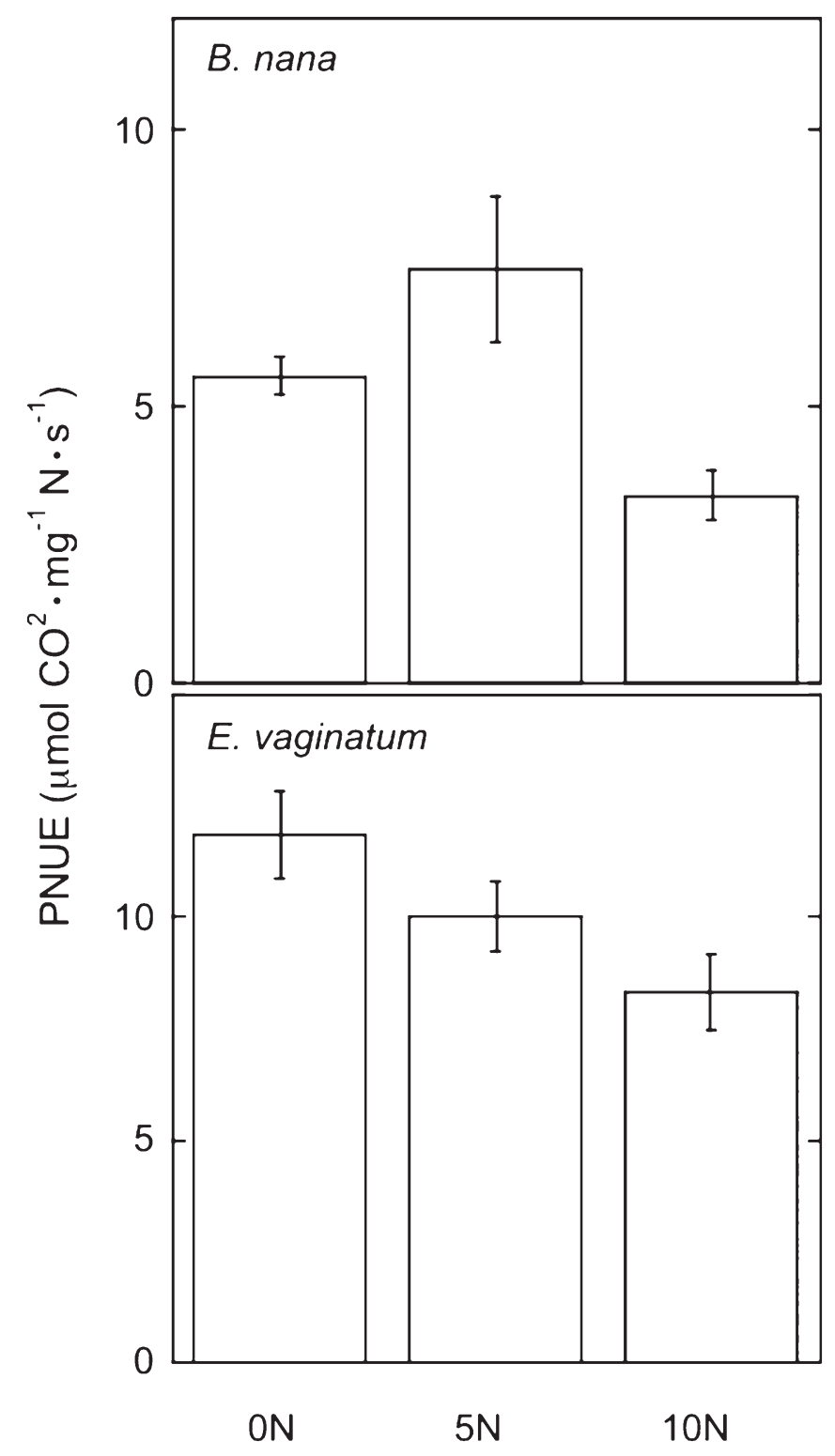

Fig. 5. Photosynthetic nitrogen use efficiency (PNUE) of Betula nana and Eriophorum vaginatum across the three fertilization treatments $(N=4)$. Values are means \pm SEM.

is nonmycorrhizal (Chapin et al., 1993; Hobbie and Hobbie, 2006); and (2) their growth forms-B. nana is a deciduous shrub requiring rapid and efficient growth during the short growing season (Bret-Harte et al., 2001), and E. vaginatum is an evergreen that retains its thick tillers through multiple winters (Fetcher and Shaver, 1983). However, considering these species together, respiration rates corresponded to leaf $\mathrm{N}$ and $\mathrm{P}$ in a linear manner (Fig. 4), as described previously in plants from different biomes (Reich et al., 1998). Comparison of coupled and uncoupled (maximal) dark respiration rates (Table 3), further emphasize species differences and suggest differing mechanisms under high nutrient fertilization: the small difference between coupled and uncoupled rates in E. vaginatum implies little unused respiratory potential, while B. nana exhibits the largest difference between coupled and uncoupled rates, perhaps indicating an increased capacity for energy production and carbon release. The ratios of photosynthesis to respiration also showed significant species effects (Table 1), with E. vaginatum demonstrating no variation in net foliar carbon exchange across fertilization levels, while $B$. nana increased from control to the $5 \mathrm{~N}$ treatment, but decreased from $5 \mathrm{~N}$ to $10 \mathrm{~N}$ (Table 2). The decoupled effect of increased respiration and decreased photosynthesis resulted in the lowest net carbon exchange under the highest fertilization, which mirrors measures of net ecosystem exchange from chamber studies (Illeris and Jonasson, 1999; Arens et al., 2008). Therefore, while rates of respiration seem more closely linked to fertilization treatments and foliar $\mathrm{N}$, the lack of a tandem increase in photosynthesis suggests the potential for greater carbon loss from Arctic plants under predicted future environmental conditions.

This study is the first to address the inhibition of respiration by light across a soil nutrient gradient and demonstrates the consistent depression of respiration rates in the light in these species. The general decrease in inhibition with higher soil nutrient availability and leaf $\mathrm{N}$ concentration (Fig. 4) supports the idea that inhibition may be relaxed under environmental conditions associated with enhanced photosynthesis to meet the increased cellular energy demand, as observed in Xanthium strumarium grown under elevated $\mathrm{CO}_{2}$ (Wang et al., 2001) and elevated $\mathrm{CO}_{2}$ and high $\mathrm{N}$ availability (Shapiro et al., 2004). Similarly, the lower inhibition and higher respiration rates of $B$. nana may be attributable to its being a deciduous shrub; shrubs allocate a substantial amount of energy expenditure to foliar growth and woody biomass accumulation, which both are enhanced under fertilization during the short Arctic growing season (Bret-Harte et al., 2001, 2002; Shaver et al., 2001). Considering these explanations, it is possible the potential overestimation of leaf and ecosystem respiration when the Kok effect is not measured or incorporated into models may be less pronounced in a future shrubbier, more N-rich tundra system.

Sensitivity of cellular organization to fertilization-In addition to describing the rates of gas exchange, this study also aimed to characterize the underlying cellular organelles that serve as the setting for photosynthesis and respiration and, to our knowledge, represents the only report of these variables in Arctic tundra species and plants under nitrogen and phosphorus treatments. Mitochondria and chloroplasts of mesophyll cells responded to fertilization treatment in terms of density, size, and total cell volume occupied (Table 4), though differed in response patterns between species (Fig. 8). The fine-structure organization of these cells appears to be dynamic and adaptable in both species. Instead of simply increasing the number of mitochondria and chloroplasts as reported in other species grown under elevated $\mathrm{CO}_{2}$ (Robertson et al., 1995; Griffin et al., 2001; Wang et al., 2004; Gomez-Casanovas et al., 2007), both the size and number of these organelles appear to shift to adapt to the new energy demand. In B. nana, this resulted in decoupled increases in organelle total volume that favored chloroplast growth over mitochondrial growth under the highest $\mathrm{N}$ and $\mathrm{P}$ availability (500\% and $27 \%$, respectively), whereas the opposite was the case in E. vaginatum (35\% and 267\%). These contrasting responses of organelle response to fertilization, and therefore assumed energy demand, underscores the differences in short-term adaptations across taxa.

Scaling from the organelles to leaf-level rates of photosynthesis and respiration did not yield obvious functional relationships, though the related increases in total organelle volume 

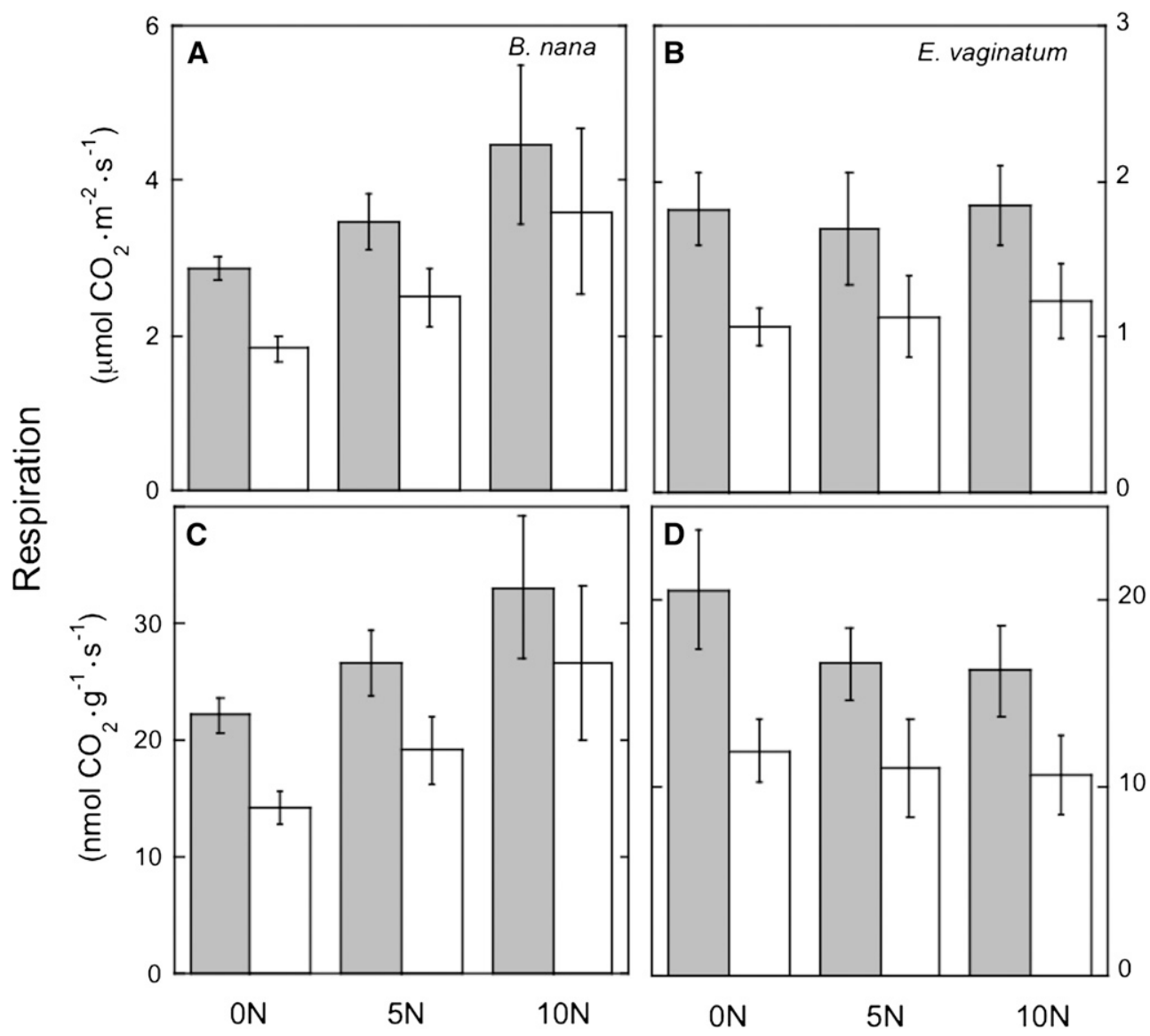

Fig. 6. Area- and mass-based rates of dark respiration (shaded) and respiration in the light (unshaded) from leaves of (A and C) Betula nana and (B and D) Eriophorum vaginatum grown under fertilization treatments of $0 \mathrm{~N}$ (control), $5 \mathrm{~N}$, and $10 \mathrm{~N}(N=4)$. Values are means $\pm \mathrm{SEM}$.

per cell corresponded slightly with respiration in both species and with photosynthesis in E. vaginatum. However, in $B$. nana, an increase in chloroplast total volume under the highest fertilization did not correlate with the depressed rates of photosynthesis. Comparison of $A: R_{\mathrm{L}}$ and $A: R_{\mathrm{D}}$ with ratios of chloroplasts to mitochondria also showed species differences in organelle-to-process relationships: the maintenance of $A: R$ despite a large drop in the relative total volume of chloroplast to mitochondria in E. vaginatum suggests an increased efficiency in chloroplasts under higher $\mathrm{N}$ and $\mathrm{P}$ availability. This increased efficiency may be due to a restructuring of grana

TABLE 3. Mean ( \pm SE) control and uncoupled (maximal) rates of oxygen consumption $\left(\mathrm{nmol} \mathrm{O} \cdot \mathrm{O} \mathrm{DM}^{-1} \cdot \mathrm{s}^{-1}\right)$ in leaf slices of Betula nana and Eriophorum vaginatum, and the percentage change under uncoupling treatment $(N=8)$.

\begin{tabular}{lccr}
\hline \hline Treatment & Control & Uncoupled & \% Change \\
\hline B. nana & & & \\
0N & $5.5 \pm 0.23$ & $6.2 \pm 0.47$ & +10.83 \\
$5 \mathrm{~N}$ & $6.5 \pm 0.63$ & $6.8 \pm 0.41$ & +4.93 \\
10N & $5.4 \pm 0.52$ & $6.9 \pm 0.74$ & +27.52 \\
E. vaginatum & & & \\
0N & $6.4 \pm 0.24$ & $7.6 \pm 0.51$ & +19.56 \\
$5 \mathrm{~N}$ & $6.5 \pm 0.51$ & $7.4 \pm 0.41$ & +14.18 \\
$10 \mathrm{~N}$ & $6.8 \pm 0.30$ & $6.8 \pm 0.51$ & +0.49 \\
\hline
\end{tabular}

and stroma thylakoids in response to potential higher photosynthetic activity, as evidenced in leaves under elevated $\mathrm{CO}_{2}$ (Griffin et al., 2001; Teng et al., 2006). However, in B. nana the opposite is evident-an increase in chloroplast to mitochondria ratio was not reflected in the lower $A: R$ ratio under higher fertilization. These discrepancies may be explained by differences in regulation-organelle biogenesis, development, and degradation occur on longer time scales than do photosynthesis and respiration, which can shift according to shortterm environmental cues. Also, it is possible that more or larger organelles do not necessarily mean they are all of equal functional efficiency (Jeong et al., 2002). Further, measurement techniques may complicate direct correlations of counts from visualizations of cell fine structure and foliar gas exchange. Organelle measurements made using transmission electron microscopy of ultrathin sections of fixed leaf tissue may limit the potential for direct scaling compared to confocal microscopy, that can localize functionally active mitochondria through staining (Logan and Leaver, 2000; Gomez-Casanovas et al., 2007). This study reports significant relationships in organelle organization under increasing fertilization in two Arctic species that suggest adaptive cellular responses and highlights the potential for future research to further elucidate and quantify the connections between these scales.

Our study incorporates measurements of photosynthesis, respiration, organelle sizes and densities, and leaf nutrients to 


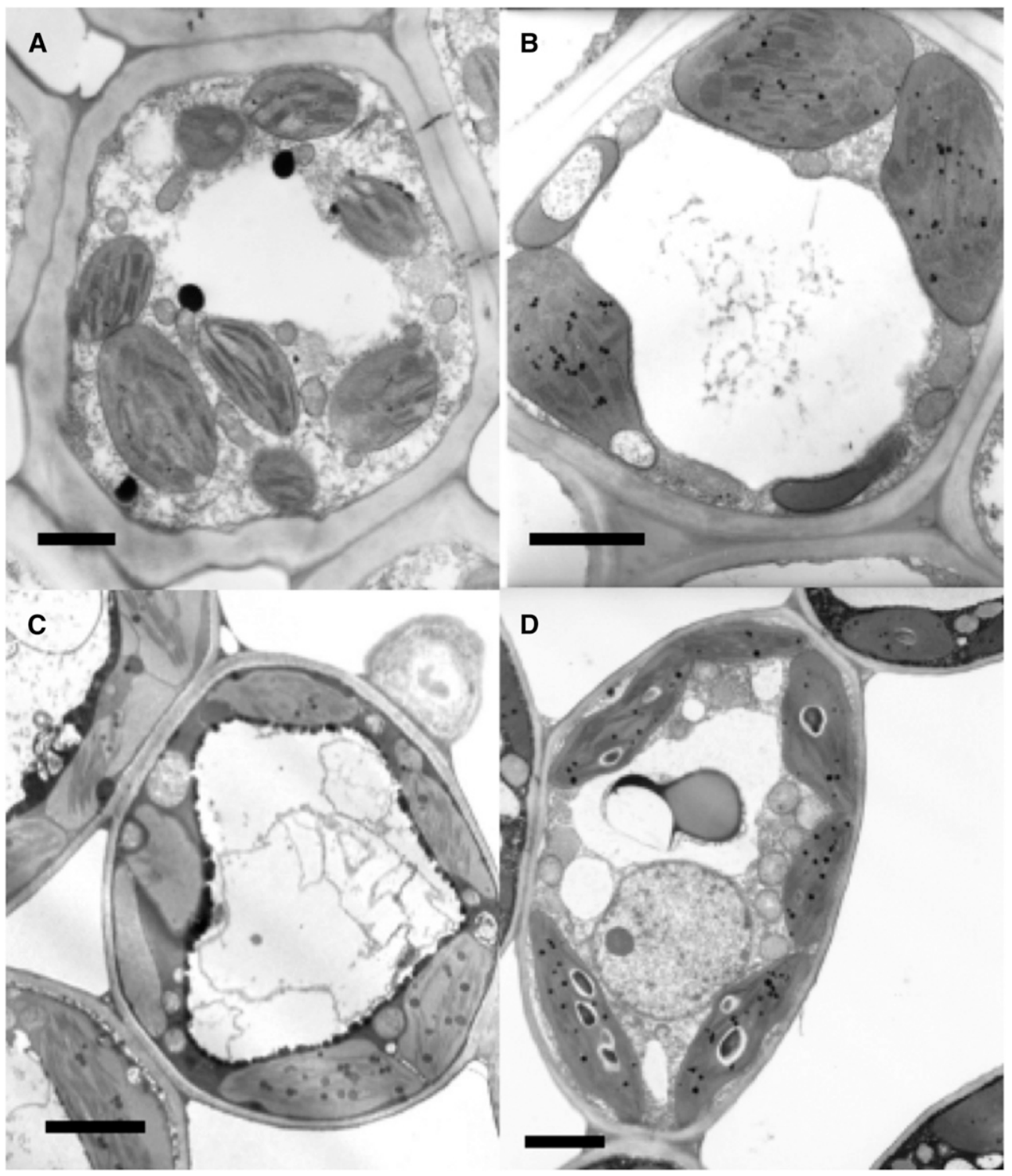

Fig. 7. Chloroplasts and mitochondria in leaf mesophyll cells of Eriophorum vaginatum grown under (A) control and (B) $10 \mathrm{~N}$ fertilization; and Betula nana under (C) control and (D) $10 \mathrm{~N}$ fertilization. Mitochondria are indicated by arrows. Starch granules were present in chloroplasts of $B$. nana under fertilization (D). Scale bars $=2 \mu \mathrm{m}$.

more accurately evaluate leaf-level $\mathrm{C}$ cycling in Arctic tundra species under increased $\mathrm{N}$ and $\mathrm{P}$ availability, as is predicted under warmer temperatures. Results presented highlight the need for leaf-level measurements to describe and predict $\mathrm{C}$ cycling

TABLE 4. Results of a two-way ANOVA comparing Betula nana and Eriophorum vaginatum and fertilization treatment effects on chloroplast (Chloro) and mitochondria (Mito) size $(N=30)$ and density $(N=45)$.

\begin{tabular}{|c|c|c|c|c|c|c|}
\hline \multirow[b]{2}{*}{ Variable } & \multicolumn{2}{|c|}{ Species $(\mathrm{df}=1)$} & \multicolumn{2}{|c|}{$\mathrm{NP}(\mathrm{df}=2)$} & \multicolumn{2}{|c|}{$\begin{array}{c}\text { Species } \times \text { NP } \\
(\mathrm{df}=2)\end{array}$} \\
\hline & $F$-ratio & $P$ & $F$-ratio & $P$ & $F$-ratio & $P$ \\
\hline Chloro density & 0.892 & 0.345 & 11.160 & $* * *$ & 2.684 & 0.070 \\
\hline Chloro size & 7.759 & $* * *$ & 8.744 & $* * *$ & 23.313 & *** \\
\hline Mito density & 12.239 & $* * *$ & 11.363 & $* * *$ & 4.553 & * \\
\hline Mito size & 5.039 & $* *$ & 15.851 & **** & 9.707 & **** \\
\hline
\end{tabular}

Notes: Significance $* P<0.05, * * P<0.01, * * * P<0.001$. in a changing environment, especially when considering foliar respiration, which is inhibited by light and can be sensitive to environmental drivers such as $\mathrm{N}$ and $\mathrm{P}$ fertilization. For accurate estimations of foliar net carbon exchange, the inhibition of respiration of light must be considered, especially in Arctic ecosystems where dark respiration measurements do not reflect reality during the night-less growing season. Neglect of this measurement can lead to inaccurate estimations of $\mathrm{C}$ exchange at the leaf, organism, and ecosystem levels. Our study also provides the first known characterizations of mitochondria and chloroplasts in Arctic species, providing further insight on the cellular adaptations to increased nutrient availability. While the decoupled and species-specific variation in foliar $\mathrm{C}$ cycling rates under increasing fertilization treatments may complicate predictions, these findings represent another degree of complexity that must be considered in the Arctic tundra under climate change. 


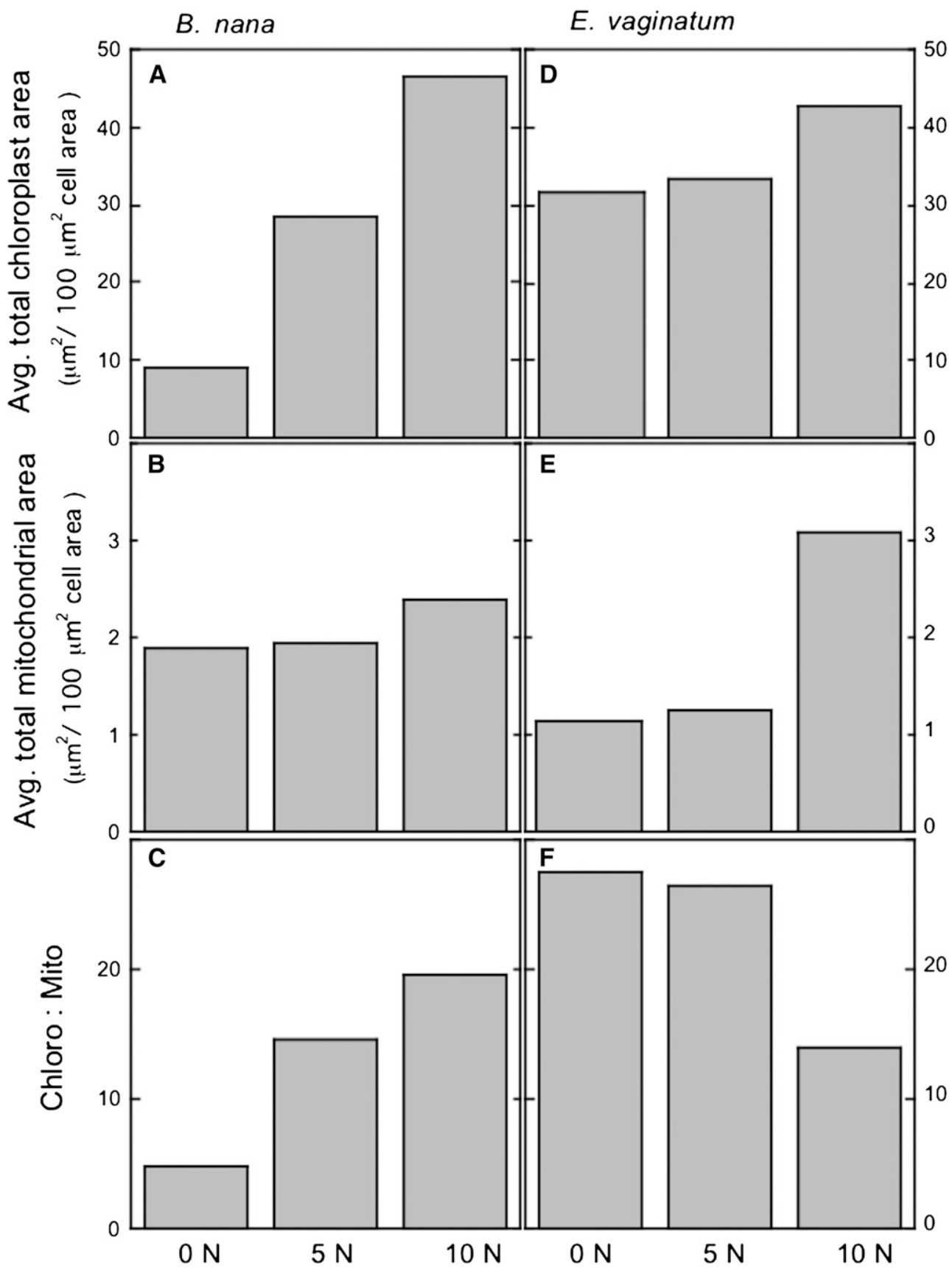

Fig. 8. Average total area of gas exchange organelles per $100 \mu \mathrm{m}^{2}$ mesophyll cell area in (A, B) Betula nana and (D, E) Eriophorum vaginatum. Values shown are the product of average chloroplast and mitochondria density and average mitochondria and chloroplast size. The ratio of the average total chloroplast area to average total mitochondria area is shown in panels $\mathrm{C}$ and F. Error bars are absent for these metrics, as they are calculated based on averages.

\section{LITERATURE CITED}

Aber, J. D., K. J. Nadelhoffer, P. Steudler, and J. M. Melillo. 1989. Nitrogen saturation in northern forest ecosystems: Excess nitrogen from fossil-fuel combustion may stress the biosphere. BioScience 39: 378-386.

ANDERSON, O. R. 2010. The reciprocal relationships between high latitude climate changes and the ecology of terrestiral microbiota: Emerging theories, models, and empirical evidence, especially related to global warming. In B. Gutierrez and C. Pena [eds.], Tundra: Vegetation, wildlife, and climate trends, 47-79. Nova Science, New York, New York, USA.

AREns, S. J. T., P. F. Sullivan, AND J. M. Welker. 2008. Nonlinear responses to nitrogen and strong interactions with nitrogen and phosphorus additions drastically alter the structure and function of a high arctic ecosystem. Journal of Geophysical Research, Biogeosciences 113: G03S09.

Armstrong, A. F., D. C. Logan, and O. K. Atrin. 2006a. On the developmental dependence of leaf respiration: Responses to short and longterm changes in growth temperature. American Journal of Botany 93: $1633-1639$. 
Armstrong, A. F., D. C. Logan, A. K. Tobin, P. O’Toole, and O. K. ATKIN. 2006b. Heterogeneity of plant mitochondrial responses underpinning respiratory acclimation to the cold in Arabidopsis thaliana leaves. Plant, Cell \& Environment 29: 940-949.

AtKIn, O. K., AND W. R. Cummins. 1994. The effect of nitrogen source on growth, nitrogen economy and respiration of two high arctic plant species differing in relative growth rate. Functional Ecology 8: 389-399.

Atkin, O. K., J. R. Evans, M. C. Ball, H. Lambers, and T. L. Pons. 2000. Leaf respiration of snow gum in the light and dark: Interactions between temperature and irradiance. Plant Physiology 122: 915-923.

Atkin, O. K., I. Scheurwater, and T. L. Pons. 2006. High thermal acclimation potential of both photosynthesis and respiration in two lowland Plantago species in contrast to an alpine cogeneric. Global Change Biology 12: 500-515.

Ayub, G., R. A. Smith, D. T. Tissue, and O. A. Atkin. 2011. Impacts of drought on leaf respiration in darkness and light in Eucalyptus saligna exposed to industrial-age $\mathrm{CO}_{2}$ and growth temperature. New Phytologist 190: 1003-1018.

Baddeley, J., S. Woodin, and I. Alexander. 1994. Effects of increased nitrogen and phosphorus availability on the photosynthesis and nutrient relations of three Arctic dwarf shrubs from Svalbar. Functional Ecology 8: 676-685.

Bauer, G. A., F. A. Bazzaz, R. Minocha, S. Long, A. Magill, J. Aber, AND G. M. Berntson. 2004. Effects of chronic N additions on tissue chemistry, photosynthetic capacity, and carbon sequestration potential of a red pine (Pinus resinosa) stand in the NE United States. Forest Ecology and Management 196: 173-186.

Boelman, N., M. Stieglitz, K. Griffin, and G. Shaver. 2005. Inter-annual variability of NDVI in response to long-term warming and fertilization in wet sedge and tussock tundra. Oecologia 143: 588-597.

Bret-Harte, M. S., E. A. García, V. M. Sacré, J. R. Whorley, J. L. Wagner, S. C. Lippert, AND F. S. Chapin III. 2004. Plant and soil responses to neighbour removal and fertilization in Alaskan tussock tundra. Journal of Ecology 92: 635-647.

Bret-Harte, M. S., G. R. Shaver, and F. S. Chapin III. 2002. Primary and secondary stem growth in arctic shrubs: Implications for community response to environmental change. Journal of Ecology 90: 251-267.

Bret-Harte, M. S., G. R. Shaver, J. P. Zoerner, J. F. Johnstone, J. L. Wagner, A. S. Chavez, R. F. Gunkelman IV, S. C. Lippert, and J. A. Laundre. 2001. Developmental plasticity allows Betula nana to dominate tundra subjected to an altered environment. Ecology 82: 18-32.

Brooks, A., AND G. FARQuHar. 1985. Effect of temperature on the $\mathrm{CO}_{2}-\mathrm{O}_{2}$ specificity of ribulose-1,5-bisphosphate carboxylase/oxygenase and the rate of respiration in the light. Planta 165: 397-406.

Budde, R. J., AND D. D. Randall. 1990. Pea leaf mitochondrial pyruvate dehydrogenase complex is inactivated in vivo in a light-dependent manner. Proceedings of the National Academy of Sciences, USA 87: 673-676.

Chapin, F. S. III, L. Moilanen, and K. Kielland. 1993. Preferential use of organic nitrogen for growth by a non-mycorrhizal arctic sedge. Nature 361: 150-153.

Chapin, F. S. III, and G. R. Shaver. 1996. Physiological and growth responses of Arctic plants to a field experiment simulating climatic change. Ecology 77: 822-840.

Chapin, F. S. III, G. R. Shaver, A. E. Giblin, K. J. Nadelhoffer, and J. A. LAUNDRE. 1995. Responses of Arctic tundra to experimental and observed changes in climate. Ecology 76: 694-711.

Chapin, F. S. III, M. Sturm, M. C. Serreze, J. P. McFadden, J. R. Key, A. H. Lloyd, A. D. McGuire, et al. 2005. Role of land-surface changes in Arctic summer warming. Science 310: 657-660.

Dowding, D., F. S. Chapin III, F. E. Wielgolaski, and P. Kilfeather. 1981. Nutrients in tundra ecosystems. In L. C. Bliss [ed.], Tundra ecosystems: A comparative analysis. Cambridge University Press, Cambridge, UK.

Environmental Data Center Team. 2009. Meteorological monitoring program at Toolik, Alaska. Toolik Field Station, Institute of Arctic Biology, University of Alaska Fairbanks, Fairbanks, Alaska, USA. Website http://toolik.alaska.edu/edc/weather/data_query.php [accessed 10 December 2011].

Fetcher, N., and G. R. Shaver. 1983. Life histories of tillers of Eriophorum vaginatum in relation to tundra disturbance. Journal of Ecology 71: 131-147.
Galloway, J. N., F. J. Dentener, D. G. Capone, E. W. Boyer, R. W. Howarth, S. P. Seitzinger, G. P. Asner, et al. 2004. Nitrogen cycles: Past, present and future. Biogeochemistry 70: 153-226.

Gomez-Casanovas, N., E. Blanc-Betes, M. A. Gonzalez-Meler, and J. AzCon-Bieto. 2007. Changes in respiratory mitochondrial machinery and cytochrome and alternative pathway activities in response to energy demand underlie the acclimation of respiration to elevated $\mathrm{CO}_{2}$ in the invasive Opuntia ficus-indica. Plant Physiology 145: 49-61.

Gorham, E. 1991. Northern peatlands: Role in the carbon cycle and probable responses to climatic warming. Ecological Applications 1: $182-195$.

Griffin, K. L., O. R. Anderson, M. D. Gastrich, J. D. Lewis, G. Lin, W. Schuster, J. R. SeEmann, et Al. 2001. Plant growth in elevated $\mathrm{CO}_{2}$ alters mitochondrial number and chloroplast fine structure. Proceedings of the National Academy of Sciences, USA 98: 2473-2478.

HiLl, S., AND J. BRYCE. 1992. Malate metabolism and light-enhanced dark respiration in barley mesophyll protoplasts. SPB Academic Publishing, The Hague, Netherlands.

Hobbie, J. E., And E. A. Hobbie. 2006. ${ }^{15} \mathrm{~N}$ in symbiotic fungi and plants estimates nitrogen and carbon flux rates in arctic tundra. Ecology 87: 816-822.

HobBIE, S. E. 1996. Temperature and plant species control over litter decomposition in Alaskan tundra. Ecological Monographs 66: 503-522.

Hobbie, S. E., K. J. Nadelhoffer, and P. Högberg. 2002. A synthesis: The role of nutrients as constraints on carbon balances in boreal and arctic regions. Plant and Soil 242: 163-170.

Hodson, A. J., P. N. Mumford, J. Kohler, And P. M. Wynn. 2005. The high Arctic glacial ecosystem: New insights from nutrient budgets. Biogeochemistry 72: 233-256.

Hoefnagel, M. H. N., O. K. AtKin, AND J. T. Wiskich. 1998. Interdependence between chloroplasts and mitochondria in the light and the dark. Biochimica et Biophysica Acta, Bioenergetics 1366: 235-255.

Hurry, V., A. U. Igamberdiev, O. Keerberg, T. PÄrnik, O. K. Atkin, J. Zaragoza-Castells, and P. Gardestrom. 2005. Respiration in photosynthetic cells: Gas exchange components, interactions with photorespiration and the operation of mitochondria in the light. In $\mathrm{H}$. Lambers and M. Ribas-Carbo [eds.], Plant respiration: From cell to ecosystem, 43-61. Springer, Dordrecht, Netherlands.

Hurry, V., O. Keerberg, T. Pärnik, G. Oquist, and P. Gardestrom. 1996. Effect of cold hardening on the components of respiratory decarboxylation in the light and in the dark in leaves of winter rye. Plant Physiology 111: 713-719.

ILleris, L., AND S. JoNASSON. 1999. Soil and plant $\mathrm{CO}_{2}$ emission in response to variations in soil moisture and temperature and to amendment with nitrogen, phosphorus, and carbon in northern Scandinavia. Arctic, Antarctic, and Alpine Research 31: 264-271.

Jeong, W. J., Y. I. Park, K. Suh, J. A. Raven, O. J. Yoo, and J. R. Liu. 2002. A large population of small chloroplasts in tobacco leaf cells allows more effective chloroplast movement than a few enlarged chloroplasts. Plant Physiology 129: 112-121.

Johnson, L., G. Shaver, D. Cades, E. Rastetter, K. Nadelhoffer, A. Giblin, J. Laundre, and A. Stanley. 2000. Plant carbon-nutrient interactions control $\mathrm{CO}_{2}$ exchange in Alaskan wet sedge tundra ecosystems. Ecology 81: 453-469.

Jonasson, S., J. CAstro, and A. Michelsen. 2004. Litter, warming and plants affect respiration and allocation of soil microbial and plant $\mathrm{C}, \mathrm{N}$, and $\mathrm{P}$ in arctic mesocosms. Soil Biology \& Biochemistry 36: 1129-1139.

Kirschbaum, M. U. F., and G. D. Farquhar. 1987. Investigation of the $\mathrm{CO}_{2}$ dependence of quantum yield and respiration in Eucalyptus pauciflora. Plant Physiology 83: 1032-1036.

Кок, В. 1948. A critical consideration of the quantum yield of Chlorellaphotosynthesis. Enzymologia 13: 1-56.

LAISK, A. 1977. Kinetics of photosynthesis and photorespiration in $\mathrm{C}_{3}$ plants. Nauka, Moscow, USSR.

Leegood, R. C., P. J. Lea, M. D. Adcock, and R. E. Hausler. 1995. The regulation and control of photorespiration. Journal of Experimental Botany 46: 1397-1414.

Logan, D. C., AND C. J. Leaver. 2000. Mitochondria-targeted GFP highlights the heterogeneity of mitochondrial shape, size and movement within living plant cells. Journal of Experimental Botany 51: 865-871. 
LundBerg, A., AND J. Beringer. 2005. Albedo and snowmelt rates across a tundra-to-forest transition. In Proceedings of 15th International Northern Research Basins Symposium and Workshop, 1-10, Luleå to Kvikkjokk, Sweden. Department of Water Resources Engineering, Lund University, Lund, Sweden.

Mack, M. C., E. A. G. Schuur, M. S. Bret-Harte, G. R. Shaver, and F. S. CHAPIN III. 2004. Ecosystem carbon storage in Arctic tundra reduced by long-term nutrient fertilization. Nature 431: 440-443.

McCashin, B. G., E. A. Cossins, and D. T. Canvin. 1988. Dark respiration during photosynthesis in wheat leaf slices. Plant Physiology 87: $155-161$.

Nadelhoffer, K. J., A. E. Giblin, G. R. Shaver, and J. A. Laundre. 1991. Effects of temperature and substrate quality on element mineralization in six arctic soils. Ecology 72: 242-253.

PÄrnik, T., H. Ivanova, and O. Keerberg. 2007. Photorespiratory and respiratory decarboxylations in leaves of $\mathrm{C}_{3}$ plants under different $\mathrm{CO}_{2}$ concentrations and irradiances. Plant, Cell \& Environment 30: $1535-1544$.

PÄrnik, T., AND O. KeERBerg. 1995. Decarboxylation of primary end products of photosynthesis at different oxygen concentrations. Journal of Experimental Botany 46: 1439-1477. doi:10.1093/jxb/46. special issue. 1439

Peisker, M., AND H. Apel. 2001. Inhibition by light of $\mathrm{CO}_{2}$ evolution from dark respiration: Comparison of two gas exchange methods. Photosynthesis Research 70: 291-298.

Pinelli, P., And F. Loreto. 2003. ${ }^{12} \mathrm{CO}_{2}$ emission from different metabolic pathways measured in illuminated and darkened $\mathrm{C} 3$ and $\mathrm{C} 4$ leaves at low, atmospheric and elevated $\mathrm{CO}_{2}$ concentration. Journal of Experimental Botany 54: 1761-1769.

Ping, C., G. Michaelson, and M. Jorgenson. 2008. High stocks of soil organic carbon in the North American Arctic region. Nature Geoscience 1: 615-619.

R Development Core Team. 2010. A language and environment for statistical computing. R Foundation for Statistical Computing, Vienna, Austria. Website http://www.R-project.org.

Rasmusson, A. G., AND M. A. Escobar. 2007. Light and diurnal regulation of plant respiratory gene expression. Physiologia Plantarum 129: 57-67.

Reich, P. B., M. B. Walters, D. S. Ellsworth, J. M. Vose, J. C. Volin, C. Gresham, and W. D. Bowman. 1998. Relationships of leaf dark respiration to leaf nitrogen, specific leaf area and leaf life-span: A test across biomes and functional groups. Oecologia 114: 471-482.

Robertson, E. J., And R. M. Leech. 1995. Significant changes in cell and chloroplast development in young wheat leaves grown in elevated CO2. Plant Physiology 107: 63-71.

Robertson, E. J., M. Williams, J. L. Harwood, J. G. Lindsay, C. J. Leaver, AND R. M. LEECH. 1995. Mitochondria increase three-fold and mitochondrial proteins and lipid change dramatically in postmeristematic cells in young wheat leaves grown in elevated $\mathrm{CO}_{2}$. American Society of Plant Biologists, Rockville, Maryland, USA.

Robinson, C. H., AND P. A. WoOKEy. 1997. Microbial ecology, decomposition, and nutrient cycling. In S. J. Woodin and M. Marquiss [eds.], Ecology of arctic environments, 41-68. Blackwell Science, Oxford, UK

Serreze, M. C., J. E. Walsh, F. S. Chapin, T. Osterkamp, M. Dyurgerov, V. Romanovsky, W. C. Oechel, J. Morison, T. Zhang, and R. G. BARRY. 2000. Observational evidence of recent change in the northern high-latitude environment. Climatic Change 46: 159-207.

Shapiro, J. B., K. L. Griffin, J. D. Lewis, and D. T. Tissue. 2004. Response of Xanthium strumarium leaf respiration in the light to elevated $\mathrm{CO}_{2}$ concentration, nitrogen availability and temperature. New Phytologist 162: $377-386$

Sharp, R. E., M. A. Matthews, and J. S. Boyer. 1984. Kok effect and the quantum yield of photosynthesis: light partially inhibits dark respiration. Plant Physiology 75: 95-101.

Shaver, G. R., W. D. Billings, F. S. Chapin III, A. E. Giblin, K. J. Nadelhoffer, W. C. Oechel, and E. B. RastetTer. 1992. Global change and the carbon balance of Arctic ecosystems. BioScience 42: 433-441.

Shaver, G. R., M. S. Bret-Harte, M. H. Jones, J. Johnstone, L. Gough, J. LAUndRe, AND F. S. Chapin III. 2001. Species composition interacts with fertilizer to control long-term change in tundra productivity. Ecology 82: 3163-3181.
Shaver, G. R., AND F. S. Chapin III. 1986. Effect of fertilizer on production and biomass of tussock tundra, Alaska, U.S.A. Arctic and Alpine Research 18: 261-268.

Shaver, G. R., L. C. Johnson, D. H. Cades, G. Murray, J. A. Laundre, E. B. Rastetter, K. J. Nadelhoffer, AND A. E. Giblin. 1998. Biomass and $\mathrm{CO}_{2}$ flux in wet sedge tundras: Responses to nutrients, temperature, and light. Ecological Monographs 68: 75-97.

Stone, R. S., E. G. Dutton, J. M. Harris, and D. Longenecker. 2002. Earlier spring snowmelt in northern Alaska as an indicator of climate change. Journal of Geophysical Research 107: 4089.

Sturm, M., C. Racine, and K. TAPe. 2001. Climate change: Increasing shrub abundance in the Arctic. Nature 411: 546-547.

Sturm, M., J. Schimel, G. Michaelson, J. M. Welker, S. F. Oberbauer, G. E. Liston, J. FAHNEStOCK, AND V. E. Romanovsky. 2005. Winter biological processes could help convert Arctic tundra to shrubland. BioScience 55: 17-26.

Takashima, T., K. Hikosaka, and T. Hirose. 2004. Photosynthesis or persistence: Nitrogen allocation in leaves of evergreen and deciduous Quercus species. Plant, Cell \& Environment 27: 1047-1054.

Tape, K., M. Sturm, and C. Racine. 2006. The evidence for shrub expansion in Northern Alaska and the Pan-Arctic. Global Change Biology 12: 686-702.

Tcherkez, G., R. Bligny, E. Gout, A. Mahe, M. Hodges, and G. Cornic. 2008. Respiratory metabolism of illuminated leaves depends on $\mathrm{CO}_{2}$ and $\mathrm{O}_{2}$ conditions. Proceedings of the National Academy of Sciences, USA 105: 797-802.

Tcherkez, G., G. Cornic, R. Bligny, E. Gout, and J. Ghashghaie. 2005. In vivo respiratory metabolism of illuminated leaves. Plant Physiology 138: 1596-1606.

Teng, N., J. Wang, T. Chen, X. Wu, Y. Wang, And J. Lin. 2006. Elevated $\mathrm{CO}_{2}$ induces physiological, biochemical and structural changes in leaves of Arabidopsis thaliana. New Phytologist 172: 92-103.

Tissue, D. T., J. D. Lewis, S. D. Wullschleger, J. S. Amthor, K. L. Griffin, AND O. R. ANDERSON. 2002. Leaf respiration at different canopy positions in sweetgum (Liquidambar styraciflua) grown in ambient and elevated concentrations of carbon dioxide in the field. Tree Physiology 22: 1157-1166.

Tovar-Méndez, A., J. A. Miernyk, and D. D. Randall. 2003. Regulation of pyruvate dehydrogenase complex activity in plant cells. European Journal of Biochemistry 270: 1043-1049.

Turpin, D. H., F. C. Botha, R. G. Smith, R. Feil, A. K. Horsey, and G. C. VANLERBERGHE. 1990. Regulation of carbon partitioning to respiration during dark ammonium assimilation by the green alga Selenastrum minutum. Plant Physiology 93: 166-175.

Villar, R., A. Held, and J. Merino. 1995. Dark leaf respiration in light and darkness of an evergreen and a deciduous plant species. Plant Physiology 107: 421-427.

Wallenstein, M. D., S. McMahon, and J. Schimel. 2007. Bacterial and fungal community structure in Arctic tundra tussock and shrub soils. FEMS Microbiology Ecology 59: 428-435.

WANG, X., O. R. ANDERson, AND K. L. GRIFFin. 2004. Chloroplast numbers, mitochondrion numbers and carbon assimilation physiology of Nicotiana sylvestris as affected by $\mathrm{CO}_{2}$ concentration. Environmental and Experimental Botany 51: 21-31.

Wang, X., J. D. Lewis, D. T. Tissue, J. R. Seemann, and K. L. Griffin. 2001 Effects of elevated atmospheric $\mathrm{CO}_{2}$ concentration on leaf dark respiration of Xanthium strumarium in light and in darkness. Proceedings of the National Academy of Sciences, USA 98: 2479-2484.

Weger, H. G., D. G. Birch, I. R. Elrifi, and D. H. Turpin. 1988. Ammonium assimilation requires mitochondrial respiration in the light: A study with the green alga Selenastrum minutum. Plant Physiology 86: 688-692.

Weintraub, M. N., And J. P. Schimel. 2005. Nitrogen cycling and the spread of shrubs control changes in the carbon balance of Arctic tundra ecosystems. BioScience 55: 408-415.

Woodin, S. J. [ed.]. 1997. Effects of acid deposition on arctic vegetation. Blackwell Science, Oxford, UK.

Wookey, P. A., R. Aerts, R. D. Bardgett, F. Baptist, K. A. Brathen, J. H. C. Cornelissen, L. Gough, et Al. 2009. Ecosystem feedbacks and cascade processes: understanding their role in the responses of Arctic and alpine ecosystems to environmental change. Global Change Biology 15: 1153-1172. 